\title{
Modelling streamflow response to climate change in data-scarce White Volta River basin of West Africa using a semi-distributed hydrologic model
}

\author{
Sulemana Abubakari, Xiaohua Dong, Bob Su, Xiaonong Hu, Ji Liu, \\ Yinghai Li, Tao Peng, Haibo Ma, Kai Wang and Shijin Xu
}

\begin{abstract}
This study uses high resolution Climate Forecast System Reanalysis (CFSR), SWAT and two IPCC climate change (CC) scenarios (A1B and B1) combined with two general circulation models (GCMs) (HADCM3 and MPEH5) to evaluate impact of CC on streamflow in the White Volta basin of West Africa. The evaluation criteria ( $R^{2}$ and NSE $>0.70$ and PBIAS within $\pm 25 \%$ ) during calibration and validation showed good simulation of the basin hydrology. Using average streamflow from 1979 to 2008 as a baseline, there were uncertainties over the sign of variation of annual streamflow in the 2020s. Annually, streamflow change is projected to be within $-4.00 \%$ to $+13.00 \%$ in the 2020 s and $+3.00 \%$ to $+16.00 \%$ in the 2050 s. Monthly streamflow changes for most months vary between $-13.00 \%$ and $+32.00 \%$. A shift in monthly maximum streamflow from September to August is projected, while the driest months (December, January and February) show no change in the future. Based on the model results, the White Volta basin will likely experience an increase in streamflow by the mid-21st century. This would call for appropriate investment into cost-effective adaptive water management practices to cater for the likely impact of CC on the future hydrology of the basin.
\end{abstract} Key words | CFSR, climate change, hydrologic modelling, LARS-WG, SWAT, White Volta River basin

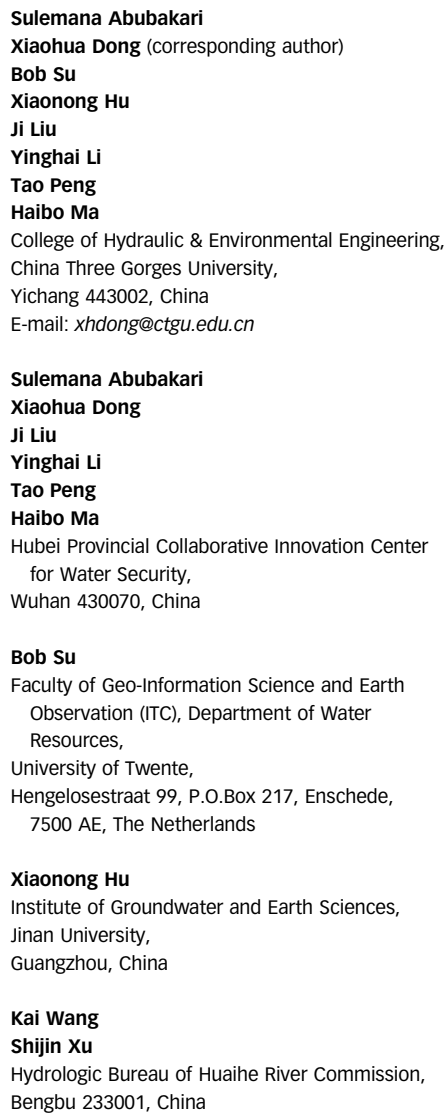

\section{INTRODUCTION}

Surface water plays a crucial role in many sectors in West Africa (WA), such as agriculture, hydropower generation, fisheries, livestock watering, recreation and tourism. Even though most of the agriculture in WA is rain-fed, some regions strongly depend on surface water. For example, the surface water impounded through large dams on the Niger, Volta, Senegal, Gambia rivers, etc., in WA serves as a major source doi: $10.2166 /$ wcc. 2018.193 of hydropower generation. The fishing sector depends strongly on river discharge. The drought conditions that occurred in WA in the 1970s and 1980s caused a drop of $-50 \%$ in fisheries production of the Niger delta, resulting in a loss of about USD 20 million per year (Neiland \& Béné 2008).

The Fifth Assessment Report (AR5) of the Intergovernmental Panel on Climate Change (IPCC) (IPCC 
2013) projects average temperatures in Africa to increase by 1.5 to $3{ }^{\circ} \mathrm{C}$ by 2050 , which is very likely to be larger than the global annual and seasonal mean warming with potential impacts on the hydrological cycle. Projections from climate models all agree on a warming in WA with its magnitude ranging from +2 to $+6^{\circ} \mathrm{C}$ in 2100 across climate models (IPCC 2007). However, precipitation projections are uncertain. Almost half of them predict an increase in rainfall and the other half a decrease (Vigaud et al. 20II; Berg et al. 2013), with changes in annual rainfall roughly ranging from -20 to $+20 \%$ (Sultan et al. 20I3).

Rainfall changes may have a direct effect on river flow. A study by Conway et al. (2009) regarding rainfall-runoff relationships on water resources variability in sub-Saharan Africa during the 20th century revealed varying behaviour including strong but non-stationary relationships, particularly in the WA sub-region with rainfall accounting for around $60 \%-70 \%$ of river flow variability. According to a study by Roudier et al. (2014), there is uncertainty on signs of the future change of streamflow in WA except for (i) the Gambia River, which exhibits a significant negative change $(-4.5 \%)$ and (ii) the Sassandra and the Niger rivers, where the change is positive $(+14.4 \%$ and $+6.1 \%)$. Correlation analysis from the same study revealed that runoff changes are highly linked to changes in rainfall $(\mathrm{R}=0.49)$, and also to a smaller extent to changes in potential evapotranspiration.

Hydrologic and climate models serve as important tools for the quantification of climate change (CC) impacts on the hydrology of a watershed. Previous studies looked at available meteorological data and used hydrological models to quantify freshwater availability in African river basins. These studies have reported a lack of detailed measured weather data and other agriculture and reservoir management data, which have hindered model development and caused high uncertainties in model results (Schuol \& Abbaspour 2006; Sood et al. 20I3). Milzow et al. (20II) investigated the utilization of combined satellite radar altimetry, surface soil moisture estimates (SSM) and Gravity Recovery and Climate Experiment (GRACE) total storage change datasets for the calibration of the Soil and Water Assessment Tool (SWAT) hydrological model in the poorly gauged Okavango watershed in Southern Africa. The study revealed that the combination of the three datasets improved the parameterization of the model. However, the model showed poor performance at a daily time step due to the lack of in-situ precipitation measurements and large variations in the three precipitation datasets. But the relatively good fit of the flow regimes suggested that the model was able to simulate the proper rainfall-runoff characteristics of the catchment and thus could be used for long-term scenario analyses.

Mango et al. (20II) used the SWAT model to investigate the impacts of land use and CC on the hydrology of the Mara River basin in Kenya. Due to the lack of climate data, rainfall estimates were obtained from the remote sensing data provided by the Famine Early Warning System (FEWS). The NSE value for the observed and simulated flows was 0.43 , while the $\mathrm{R}^{2}$ value was 0.56 . Although the correlation results were not satisfactory for the accurate prediction of flows in the river basin, the data could be utilized for a better understanding of the hydrological processes in the basin. Schuol \& Abbaspour (2006) applied a weathergenerator algorithm based on weather statistics from the UK Climate Research Unit as input into SWAT model for modelling poorly gauged and data-scarce WA basins like the Niger, Volta and Senegal. Their model calibration results showed mixed performance, with some calibrating stations giving Nash-Sutcliffe values of over 0.7 while others produced values below -1.0. Schuol et al. (2008) applied SWAT for the estimation of freshwater availability in $18 \mathrm{WA}$ countries covering about 4 million $\mathrm{km}^{2}$. In Volta River basin, Sood et al. (20I3) used a SWAT model to evaluate the impact of dynamically downscaled A1B CC scenario on flows for 2021-2050 and 2071-2100, using 1983-2012 as the reference period. Due to data constraints, calibration was done in multiple steps, with the most upstream subbasins calibrated first and the most downstream last. The calibrated model performed well for downstream gauging stations but poorly for upstream gauging stations. Overall, the results revealed increased variability and a decrease of up to $40 \%$ in river flow as a consequence of decreasing rainfall and increasing temperature. Wagner et al. (2006) attempted to quantify the spatial and temporal changes in the hydrology of the Volta basin. They concluded that at a larger spatial scale, the effect that lack of meteorological data had on model performance was moderate and that the model could be used reasonably for the 'contemporary' estimation of the hydrology of the basin (Sood et al. 20I3). 
The freshwater resource of the White Volta River basin of WA is vital for the economic growth and social development of the riparian countries (Burkina Faso and Ghana). Previous studies (Jung \& Kunstmann 2007; Laux et al. 2008; Van de Giesen et al. 2010; Lacombe et al. 2012; Sood et al. 2013), revealed significant changes in both spatial and temporal distribution of rainfall in the basin with some sub-catchments having abundant fresh water, leaving others with very limited water to satisfy increasing demands. Gyau-Boakye \& Tumbulto (2006) computed reductions in the average annual rainfall and river discharges of up to $12 \%$ and $35 \%$, respectively, in some areas of the Volta basin and on major tributaries of the Volta River, respectively, in the period 1971-1991, relative to 1951-1970. Oguntunde et al. (2006) applied the Mann-Kendall statistic to assess trends and variability of hydro-climatology of the Volta basin in WA from 1901 to 2002. Their results revealed that a $10 \%$ relative decrease in precipitation accounted for a 16\% decrease in runoff between 1936 and 1998. These factors have significant impact on water availability within the basin. Anthropogenic pressures and CC are likely to aggravate these situations. The basin's population is projected to grow at an annual rate of $2.5 \%$ (Obuobie et al. 2012). This will likely result in significant increase in water demand, particularly for crops and livestock production in the near future. According to Roudier et al. (2014), due to population growth in WA, water withdrawals have increased by 31\% between 1983-1987 and 1998-2002 and would increase much more in the future as food demand quintuples by 2050 in the region. The ongoing global CC will place further constraints on the already limited water resources in the basin, resulting in non-attainment of the Millennium Development Goals in areas such as health, eradicating poverty and hunger (Kankam-Yeboah et al. 20r3).

Numerous studies have attempted to utilize climate models in quantifying effects of CC on hydrology and water resources management in the data-scarce White Volta River basin of WA. Obuobie (2008) used precipitation and temperature for 1991-2000 and 2030-2039 generated by stochastic downscaling model, Long Ashton Research Station Weather Generator (LARS-WG) and reflecting MM5-simulated monthly changes, future CC scenario IS92a and SWAT model to evaluate effects of CC on recharge of groundwater in the White Volta River basin.
Results of this study found an increase in mean annual rainfall of about $6 \%$ in 40 years, resulting in an increase of about $29 \%$ in groundwater recharge. Kankam-Yeboah et al. (2013) used an ensemble of two general circulation models (GCMs) (ECHAM4 and CSIRO) downscaled using LARS-WG, A1F1 future CC scenario and SWAT model to estimate impacts of CC on streamflow in the White Volta basin. Results of this study found that mean annual streamflow showed a decrease of $22 \%$ and $50 \%$ for 2006-2035 (2020s) and 2036-2075 (2050s), respectively, relative to the baseline (1961-1990). Awotwi et al. (20I5) assessed impacts of CC on various water balance components of the White Volta basin using downscaled CC projections from Regional Climate Model (REMO), A1B future CC scenario and SWAT model. Results of this study revealed that an increase of $8 \%$ and $1.7 \%$ of mean annual precipitation and temperature, respectively, in 2030-2043 leads to an increase of 26\% in mean annual surface runoff relative to the baseline (19952008).

The focuses of these studies were aimed at investigating the response of streamflow to $\mathrm{CC}$ under a single future emission scenario. However, due to uncertainties in climate projections, the use of different climate models and multiple scenarios will be useful for understanding the range of CC impact that can be expected on water resources in the White Volta River basin (Obuobie \& Diekkrüger 2008; Kankam-Yeboah et al. 20I3).

The main objective of this study therefore was to evaluate the $\mathrm{CC}$ effect on the future streamflow in the data-scarce White Volta River basin of WA using different climate models and multiple scenarios. To achieve this objective, high resolution $\left(0.3^{\circ} \sim 3 \mathrm{~km}\right)$ Climate Forecast System Reanalysis (CFSR), SWAT hydrologic model and different GCMs were used for CC impact assessment. The SWAT model was calibrated using an automatic calibration algorithm to simulate the streamflow at Nawuni (outlet) of the White Volta River basin. Next, the future precipitation and temperature changes projected by different GCMs under various CC scenarios were input into SWAT to project future annual, monthly and seasonal streamflow changes.

The results obtained in this study are expected to provide more insight into the availability of future streamflow, and to provide local water management authorities and policy makers with quantitative data for the appropriate 
design and management of water resources as well as for incorporation into $\mathrm{CC}$ adaptation strategies to reduce vulnerability and ensure water security within the basin.

\section{MATERIALS AND METHODS}

\section{Study area}

The White Volta basin (Figure 1) is a major sub-basin of the Volta River basin of WA. It is located between latitude $8^{\circ} \mathrm{N}$ and $15^{\circ} \mathrm{N}$, and longitude $1^{\circ} \mathrm{E}$ and $4^{\circ} \mathrm{W}$. It is a transboundary river basin with a drainage area of about $106,300 \mathrm{~km}^{2}$ and shared mainly by Burkina Faso and Ghana. The topography is predominantly flat with more than half of the basin lying in the elevation range of 200-300 $\mathrm{m}$ with mean elevation of about $270 \mathrm{~m}$. The basin has two major climate zones: semi-arid climate in the north and humid climate in the south. Mean annual rainfall in the semi-arid north is around $600 \mathrm{~mm}$ while that in the humid south is around 1,200 mm (Oguntunde et al. 2006). The basin experiences a high variability in rainfall between wet and dry seasons as well as from one place to another. There is a prolonged dry season of about seven months in most areas. In addition, there is the ephemeral nature of many rivers and streams in the basin. A water balance study of the Volta basin by Andreini et al. (2000) revealed that runoff is extremely sensitive to rainfall and that in the White Volta basin about $17 \%$ of the rainfall results in runoff to Lake Volta. The temporal variability of the annual runoff is higher than that of rainfall. This has been attributed to a non-linear response of runoff to rainfall and to threshold effects in the basin (Andreini et al. 2000). The monthly stream discharge in the basin has a mono-modal pattern with the peak occurring in September.

In the semi-arid north, mean monthly temperature ranges from $36^{\circ} \mathrm{C}$ in March to $27^{\circ} \mathrm{C}$ in August while in the humid south, it ranges from $30^{\circ} \mathrm{C}$ in March to $24^{\circ} \mathrm{C}$ in August. The basin's mean annual temperature and potential evapotranspiration (PET) are $26^{\circ} \mathrm{C}$ and $1,650 \mathrm{~mm}$, respectively (Oguntunde et al. 2006).

The soils in the basin are Luvisols, Regosols, Lithosols, Vertisols, Planosols, Cambisols and Gleysols. The basin is dominated by Luvisols, Regosols and Lithosols, which cover about $70 \%$ of the basin area. The land use/cover is predominantly savannah, grassland and agriculture with small patches of forest.

\section{SWAT model description}

SWAT is a process-based model for continuous hydrologic simulations. It was developed by the United States Department of Agriculture (USDA), Agricultural Research Service (ARS) to predict impact of land use practices on water, sediment and agricultural chemical yields in large and complex watersheds with diverse weather, varying soils, land use and management and topographic conditions over long periods (Neitsch et al. 2009). In several regions around the world and WA, SWAT has been used to simulate watershed hydrology and for estimating impacts of climate and land-use changes on streamflow and sediment yield (Obuobie et al. 20I2; Coffey et al. 20I5; Solaymani \& Gosain 20I5; Zang 20I7). It uses a geographic information system (GIS) interface and operates on daily time step; however, daily outputs can be aggregated into monthly and annually outputs.

The hydrological components of a river basin modelled by SWAT are given by the soil water balance of a river basin, which is represented as (Arnold et al. I998):

$S W_{t}=S W_{o}+\sum_{i=1}^{t}\left(R_{\text {day }}-Q_{\text {surf }}-E_{a}-W_{\text {seep }}-Q_{g w}\right)$

where: $S W_{t}$ is the final soil water content $(\mathrm{mm}), S W_{o}$ is the initial soil water content on day $i(\mathrm{~mm}), R_{\text {day }}$ is the amount of precipitation on day $i(\mathrm{~mm}), Q_{\text {surf }}$ is the amount of surface runoff on day $i(\mathrm{~mm}), E_{a}$ is the amount of evapotranspiration on day $i(\mathrm{~mm}), W_{\text {seep }}$ is the amount of water entering the vadose zone from the soil profile on day $i(\mathrm{~mm}), Q_{g w}$ is the amount of return flow on day $i(\mathrm{~mm})$.

The SWAT model requires a digital elevation model (DEM), soil and land-use maps and data, climate and hydrological data, for modelling a river basin. The model uses the DEM to divide a river basin into multiple sub-basins which are further subdivided into hydrologic response units (HRUs). Each HRU is made up of homogeneous land-use, management and soil characteristics (Gassman et al. 2007). The HRUs make it possible to assess the impact of the different land-use types, soil properties and management 


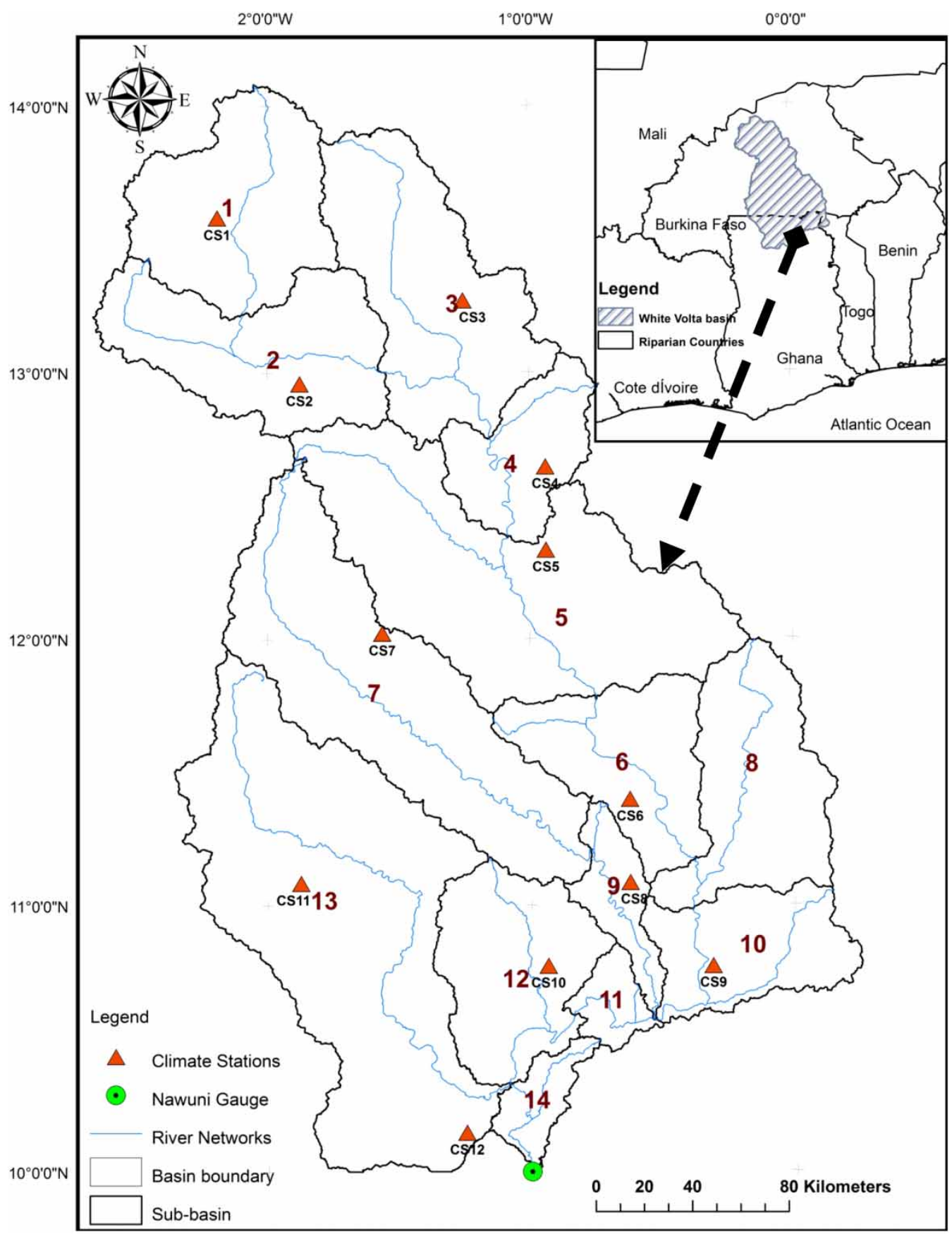

Figure 1 | Map of the White Volta River basin.

practices on the hydrology of a basin. To provide a better physical description of the water balance of a river basin, SWAT simulates the hydrological processes separately for each HRU and routes them to obtain the total runoff (Neitsch et al. 2009). In the SWAT model, there are two options for determining the HRU distribution. The options are to assign a single or multiple HRU to each sub-basin. This study utilized the Penman-Monteith method in computing the potential evapotranspiration. The input data for this option are solar radiation, air temperature, relative 
humidity and wind speed. Surface runoff volumes were quantified in the model using the modified SCS curve number, which is a function of antecedent soil moisture conditions, land use and soil permeability. The SCS curve number method employs an empirical model with an empirical relationship between rainfall and runoff that provides a consistent, reliable and accurate basis for estimating the amount of runoff variation under different land-use and soil types (Kankam-Yeboah et al. 20I3). The SCS curve number equation is given by (USDA-SCS 1972):

$Q_{\text {surf }}=\frac{\left(R_{\text {day }}-I_{a}\right)^{2}}{\left(R_{\text {day }}-I_{a}+S\right)}$

where: $Q_{\text {surf }}$ is the accumulated runoff (rainfall excess) in $(\mathrm{mm}), R_{d a y}$ is the rainfall depth for the day $(\mathrm{mm}), I_{a}$ is the initial abstraction which includes surface store, interception and infiltration prior to runoff $(\mathrm{mm}), S$ is the retention parameter $(\mathrm{mm})$ and it is defined as:

$S=25.4\left(\frac{100}{C N}-10\right)$

where: $C N$ is the curve number for the day. $I_{a}$ is commonly given as $0.2 S$. Hence, Equation (2) becomes:

$Q_{\text {surf }}=\frac{\left(R_{\text {day }}-0.2 S\right)^{2}}{\left(R_{\text {day }}+0.8 S\right)}$

Runoff is generated only when $R_{d a y}>I_{\mathrm{a}}$. A detailed description of SWAT can be obtained from Neitsch et al. (2009).

\section{Model input data and set-up}

The SWAT model requires a digital elevation model (DEM), soil and land-use maps and data, climate and discharge data, for modelling a river basin. The DEM used for this study has a spatial resolution of $90 \mathrm{~m}$ and was obtained from the Shuttle Radar Topographical Mission (SRTM) (CGIAR-CSI 2009). The DEM was used for the delineation of the watershed which included slopes' definition, defining stream networks, defining outlets and inlets of the river basin and calculation of the sub-basin parameters. The land-use/ cover (LULC) map used is a modified Food and Agricultural Organization (FAO) map with a spatial resolution of $400 \mathrm{~m}$ which exists in a raster format. It was obtained from the WaterBase project (WaterBase 2008a). Land-use types are based on FAO Land Cover Classification System (LCCSS) and had to be re-modified to match the land-cover classes in SWAT. Based on the LULC map, about $71.0 \%$ of the White Volta basin's land use is savannah, $24.1 \%$ is agriculture, $4.7 \%$ is grassland, $0.1 \%$ is forest and $0.1 \%$ is wetland.

The soil map is a FAO digitized soil map of the world and derived soil properties. It has a spatial resolution of $10 \mathrm{~km}$ and was obtained from the WaterBase Project (WaterBase 2008b). The soil data were used for determining the texture, bulk density, saturated hydraulic conductivity, organic carbon content and available water content for the different layers of each soil type.

The climate data used for this study are the National Centers for Environmental Prediction (NCEP) Climate Forecast System Reanalysis (CFSR). The CFSR weather was obtained from the Texas A\&M University spatial sciences website (globalweather.tamu.edu) (Globalweather 20I7). It consists of daily rainfall, maximum and minimum temperature, wind speed, relative humidity and solar radiation. The CFSR weather is produced using cutting-edge dataassimilation techniques (both conventional meteorological gauge observations and satellite irradiances) as well as highly advanced (and coupled) atmospheric, oceanic and surface-modelling components at $\sim 30 \mathrm{~km}$ resolution (Saha et al. 2010). CFSR was used due to the basin's sparse climate station networks and also due to most of the measured data having many missing and erroneous data. According to some studies (Dile \& Srinivasan 20I4; Fuka et al. 20I4), utilizing the CFSR precipitation and temperature data to force a watershed model provides stream discharge simulations that are as good as or better than models forced using traditional weather gauging stations.

Monthly observed discharge data for Nawuni stream gauge representing the outlet of the basin was obtained from the Global Runoff Data Centre (GRDC), Koblenz, Germany. Some of the gaps in the data were filled using the spatio-temporal dynamic model employing the Kalman smoother and the expectation maximization algorithm developed by Amisigo et al. (2008). 
The monthly observed discharge data were used for performing sensitivity analysis, calibration and validation of the SWAT model. The SWAT model set-up for the White Volta River basin (Figure 2) was done through the ArcSWAT 2009 interface following a step-by-step procedure outlined in the SWAT user guide. The model set-up was in five stages: data preparation, sub-basin discretization, HRU definition, parameter sensitivity analysis and calibration and model evaluation. All the spatial input datasets, i.e., the soil map, LULC map and the DEM were projected to the same projection, WGS84 UTM Zone $30 \mathrm{~N}$, which is the projection of the basin.

Each basin was divided into sub-basins based on the DEM and stream networks of the basin. The number of sub-basins obtained was determined by the threshold input value for defining drainage area in the SWAT model. Threshold drainage area was set to a pre-defined value of $5,500.293 \mathrm{~km}^{2}$ and this resulted in 14 sub-basins. Sub-basin delineation was followed by calculation of sub-basin parameters and subdivision of sub-basins into hydrologic response units (HRUs). The HRU analysis tool was used to load the LULC, soil layers to the project. The LULC and soil were reclassified in order to match that in SWAT, and the basin's slopes were also defined. After land-use, soil and slope definition, they were then overlaid for HRU definition. This study employed the multiple HRU option. Since the topography of the basin is predominantly flat, with about $96 \%$ of the land having slopes less than 5\%; the single slope class option was used. Each sub-basin was divided into HRUs according to the land use and soil types. Based on the guidelines of HRU definition provided by Neitsch et al. (2009), and studies by Akpoti et al. (2016) and Kankam-Yeboah et al. (20I3), land-use class percentage over sub-basin area was set to $20 \%$, soil class percentage over land-use area was set to $10 \%$ and slope class percentage over soil area was set to $20 \%$. This created 67 HRUs.

The CFSR weather data were obtained for a bounding box of latitude $6^{\circ}-16^{\circ} \mathrm{N}$ and longitude $2^{\circ} \mathrm{E}-5^{\circ} \mathrm{W}$. The weather data were prepared in .dbf format and imported to the SWAT model database. The weather station data in SWAT were linked to the centroid of each sub-basin. The model was set up and run using climate data from 1979 to 2008.

Parameter sensitivity was assessed with respect to model performance in terms of monthly flows by using the automatic sensitivity analysis tool incorporated in the SWAT model. The SWAT model employs the Latin Hypercube One-factor-At a-Time (LH-OAT) method proposed by

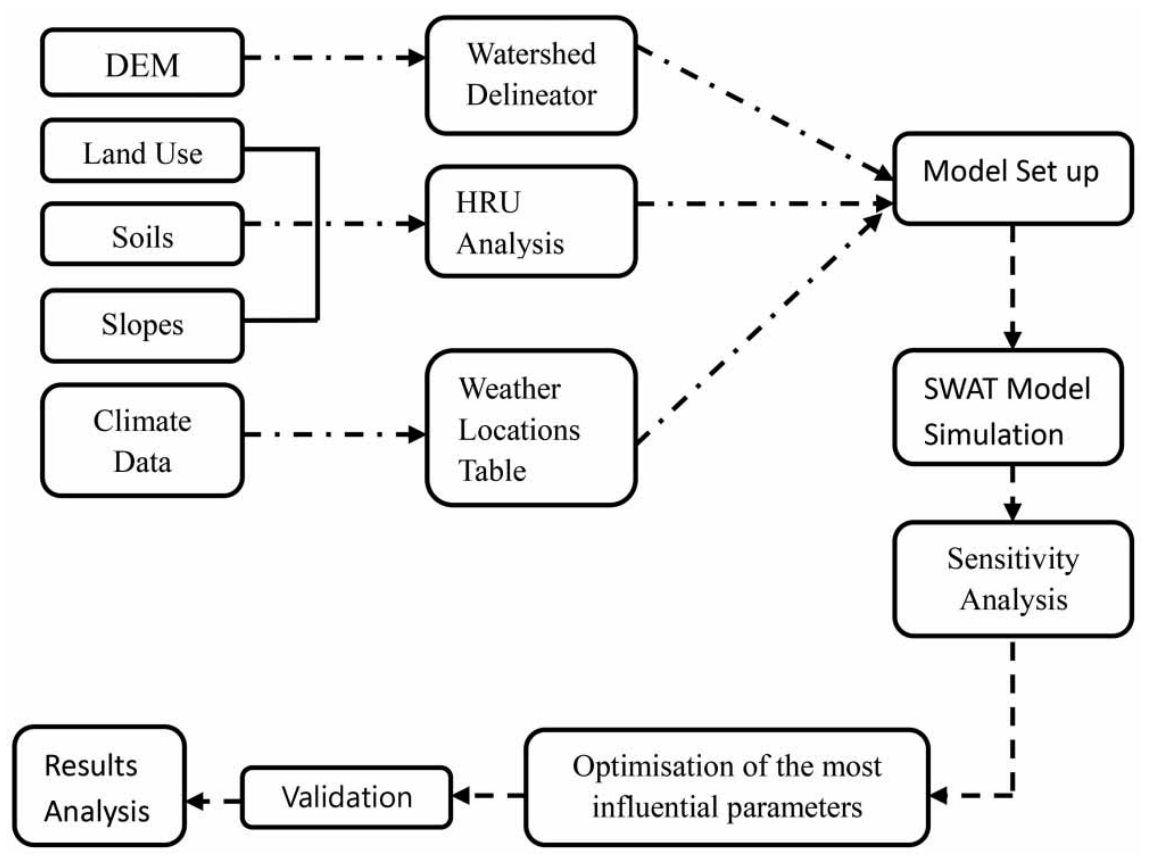

Figure 2 | Flow chart of the steps in the SWAT model application in the White Volta basin (adapted from Akpoti et al. 2016). 
Morris (I99I) to perform the sensitivity analysis. The LHOAT method integrates the Latin Hypercube (LH) sampling (global sensitivity analysis method) and the One-factor-At-aTime (OAT) design (local sensitivity analysis method), and employs the LH samples as initial points for an OAT design (van Griensven et al. 2002) and can efficiently provide a rank ordering of parameter importance. SWAT parameters (Table 1) used in similar studies in the basin (Kankam-Yeboah et al. 2013; Sood et al. 2013; Awotwi et al. 2015; Akpoti et al. 2016) served as guidelines in the selection of the parameters for sensitivity analysis. Twentyone parameters were selected and subjected to sensitivity analysis. The main aim of this analysis was to determine the model parameters that had greatest influence on the model output. Only the most influential parameters were optimized in the calibration procedure and this went a long way to minimize greatly parameter uncertainty and also the total time spent during the calibration process.
The detailed description of the SWAT input parameters can be found in Neitsch et al. (2009).

Since only the monthly observed flow data at the outlet gauging station (Nawuni) were available, calibration was performed on monthly time step. This was done to minimize the differences between simulated and measured monthly flows by adjusting the selected SWAT model parameters. In this study, we applied an automatic single-objective calibration based on PARASOL (Parameter Solutions method) developed by Van Griensven et al. (2002). Because of the non-linearities in the SWAT model, we further opted for a global search optimization algorithm. We applied the shuffled complex evolution algorithm (SCE-UA) developed by Duan et al. (1992). The time span selected for calibration was 1985-1991, with the first two years as a warm-up period. Thus, 1987-1991 was used for actual calibration and 1985-1986 was used as the warm-up period. The validation period was 1992-1996.

\begin{tabular}{|c|c|c|c|c|}
\hline No. & Parameter & Description & Lower and upper bounds & Initial value \\
\hline 1 & Alpha_Bf & Baseflow alpha factor (-) & $0-1^{\mathrm{a}}$ & 1 \\
\hline 2 & Blai & Maximum potential leaf area index (-) & $0-1^{\mathrm{a}}$ & 61 \\
\hline 3 & Canmx & Maximum canopy storage $\left(\mathrm{mmH}_{2} \mathrm{O}\right)$ & $0-10^{\mathrm{a}}$ & 7 \\
\hline 4 & Ch_Erod & Channel erodibility factor $(-)$ & $0-1^{\mathrm{a}}$ & 50 \\
\hline 5 & Ch_K2 & Channel effective hydraulic conductivity ( $\mathrm{mm} / \mathrm{hr})$ & $0-150^{\mathrm{a}}$ & 54 \\
\hline 6 & Ch_N2 & Manning's value for main channel (-) & $0-1^{\mathrm{a}}$ & 51 \\
\hline 7 & $\mathrm{Cn} 2$ & SCS runoff curve number $(-)$ & $\pm 25^{\mathrm{a}}$ & 10 \\
\hline 8 & Epco & Plant uptake compensation factor $(-)$ & $0-1^{\mathrm{a}}$ & 28 \\
\hline 9 & Esco & Soil evaporation compensation factor $(-)$ & $0-1^{\mathrm{a}}$ & 27 \\
\hline 10 & Gw_Delay & Groundwater delay (days) & $\pm 10^{\mathrm{a}}$ & 2 \\
\hline 11 & Gw_Revap & Groundwater revap coefficient (-) & $\pm 0.036^{\mathrm{a}}$ & 3 \\
\hline 12 & Gwqmn & Threshold water depth in the shallow aquifer for return flow to occur $\left(\mathrm{mm} \mathrm{H}_{2} \mathrm{O}\right)$ & $\pm 1,000^{\mathrm{a}}$ & 6 \\
\hline 13 & Rchrg_Dp & Deep aquifer percolation coefficient $(-)$ & $0-1^{\mathrm{a}}$ & 4 \\
\hline 14 & Revapmn & Threshold depth of water in the shallow aquifer for 'revap' to occur $\left(\mathrm{mm} \mathrm{H}_{2} \mathrm{O}\right)$ & $\pm 100^{\mathrm{a}}$ & 5 \\
\hline 15 & Slope & Mean slope steepness $\left(\mathrm{mm}^{-1}\right)$ & $\pm 25^{\mathrm{b}}$ & 23 \\
\hline 16 & Slsubbsn & Mean slope length (m) & $\pm 25^{\mathrm{a}}$ & 24 \\
\hline 17 & Sol_Alb & Moist soil albedo (-) & $\pm 25^{\mathrm{a}}$ & 22 \\
\hline 18 & Sol_Awc & Soil available water capacity $\left(\mathrm{mm} \mathrm{H}_{2} \mathrm{O} / \mathrm{mm}\right.$ soil $)$ & $\pm 25^{\mathrm{b}}$ & 17 \\
\hline 19 & Sol_K & Saturated hydraulic conductivity $(\mathrm{mm} / \mathrm{hr})$ & $\pm 25^{\mathrm{a}}$ & 15 \\
\hline 20 & Sol_Z & Depth from soil surface to bottom layer (mm) & $\pm 25^{\mathrm{a}}$ & 16 \\
\hline 21 & Surlag & Surface runoff lag time (days) & $0-10^{\mathrm{a}}$ & 33 \\
\hline
\end{tabular}

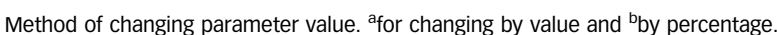


Model performance at calibration and validation was analyzed using three quantitative statistics: Nash-Sutcliffe efficiency (NSE) (Nash \& Sutcliffe 1970), the co-efficient of determination $\left(\mathrm{R}^{2}\right)$ and the percent bias (PBIAS) (Equations (5)-(7), respectively). Model performance for monthly streamflow calibration was considered acceptable when $\mathrm{R}^{2}>0.60$, NSE $>0.50$ and PBIAS was within $\pm 25 \%$ (Moriasi et al. 2007):

$$
\begin{aligned}
& N S E=1-\frac{\sum_{i=1}^{N}\left(O_{i}-P_{i}\right)^{2}}{\sum_{i=1}^{N}\left(O_{i}-\bar{O}\right)^{2}} \\
& R^{2}=\left\{\frac{\sum_{i=1}^{N}\left(O_{i}-\bar{O}\right)\left(P_{i}-\bar{P}\right)}{\left[\sum_{i=1}^{N}\left(O_{i}-\bar{O}\right)^{2}\right]^{0.5}\left[\sum_{i=1}^{N}\left(P_{i}-\bar{P}\right)^{2}\right]^{0.5}}\right\} \\
& \text { PBIAS }=\frac{\sum_{i=1}^{N}\left(O_{i}-P_{i}\right)}{\sum_{i=1}^{N}\left(O_{i}\right)} \times 100
\end{aligned}
$$

where: $O_{i}$ is the measured data, $P_{i}$ is the simulated data, $\overline{\mathrm{O}}$ is the mean of the measured data, $\bar{P}$ is the mean of the simulated data, and $N$ is the total number pairs of simulated and observed data.

\section{Climate change scenarios and projections}

The IPCC A1B and B1 scenarios were used for climate change (CC) projections. The A1B scenario emanates from the IPCC, A1 that describes a future of balanced socioeconomic and environmentally based development while emission scenario B1 describes a future development that will be more environmentally based than at present (Nakicenovic et al. 2000).

The A1B and B1 scenarios were chosen by Ghana Meteorological Agency (GMET) because they are two of the six illustrative scenarios of the IPCC and represent medium and low concentrations of greenhouse gases $\left(\mathrm{CO}_{2}, \mathrm{NH}_{4}\right.$ and $\left.\mathrm{N}_{2} \mathrm{O}\right)$, respectively, projected to be emitted in the 2020s and 2050s (IPCC 2007).

The rainfall and temperature projections were obtained from the outputs of two global climate models (GCMs): HadCM3 developed by the Hadley Centre for Climate Prediction and Research/Met Office (UK) and MPEH5 (ECHAM5) developed by the Max Planck Institute for Meteorology
(Germany). These GCMs were selected because: (1) they are two of the major models used in the IPCC Fourth Assessment Report; (2) HADCM3 simulates climate variables better than other GCMs (Stott et al. 2000; Reichler \& Kim 2008); and (3) MPEH5 (ECHAM5) was also selected because for WA, it produces temperature and rainfall results that lie approximately in the middle of the band of projections produced from the ensemble of 19 global circulation models (Roeckner et al. 2003; Sood et al. 20I3). These two GCMs have been used for climate change studies in Africa, WA and the Volta River basin (Andah et al. 2003; Ruelland et al. 2012; Sood et al. 2013).

HADCM3 and MPEH5 (ECHAM5) GCMs have spatial resolutions of $3.75^{\circ}$ longitude $\times 2.5^{\circ}$ latitude $(417 \mathrm{~km} \times$ $228 \mathrm{~km})$ and $1.90^{\circ}$ longitude $\times 1.90^{\circ}$ latitude $(211 \mathrm{~km} \times$ $173 \mathrm{~km})$, respectively. The spatial resolutions of these two GCMs are too coarse to assess the regional effects of climate change (Snell et al. 2000). This necessitated the downscaling of the two GCM outputs through the use of the stochastic downscaling model, Long Ashton Research Station Weather Generator (LARS-WG) (Semenov \& Barrow I997). In LARSWG, the historical observed daily precipitation data for a weather station for each month are analysed using a firstorder Markov chain to obtain statistical characteristics, such as the number of dry days and wet days as well as the mean and distribution of the daily precipitation for each month of the year. The minimum and maximum temperatures and solar radiation are modelled using different semiempirical distributions. Temperature is assumed to have a normal distribution, with the mean and standard deviation varying daily according to a finite Fourier series. For minimum and maximum temperatures, time series auto-correlations are assumed to be constant throughout the year for a particular site while for solar radiation, semi-empirical distributions with equal interval sizes are used (Semenov \& Barrow 1997). LARS-WG was selected for downscaling because it is freely available, easy to use, computationally inexpensive and allows for incorporation of variability into scenarios (Kankam-Yeboah et al. 20I3). The process of GCM downscaling using LARS-WG can be divided into three distinct steps, namely, bias correction (site analysis), model validation ( $Q$ test) and generation of synthetic weather data (generator). The bias correction (site analysis) step involves the analyses of observed weather data to determine their statistical characteristics and storage of this information in two files: (1) a 
parameter file which contains the parameters required by LARS-WG to generate synthetic weather time-series and (2) a statistics file containing the seasonal frequency distributions for wet and dry series length and for hot and cold spells, which is used in the model validation ( $\mathrm{Q}$ test) process. Once LARS-WG has been bias corrected using observed station data, the next step in the process is model validation (Q test), i.e., to determine how well the model performs so as to assess the ability of LARS-WG to simulate the climate at the chosen station. This is done using the generator option to synthesize daily weather data based on the information in the station parameter files obtained during the site analysis step and then undertake comparisons between the observed and synthetic data based on t-test, F-test and chi-square goodness of fit test. Each test produces a $p$-value that measures the probability that both data come from the same distribution. Once LARS-WG has been calibrated using observed weather data for a station (site analysis) and the performance of the weather generator has been verified (Q test), synthetic weather data which have the same statistical characteristics as the observed weather data, or synthetic weather data corresponding to a scenario of $\mathrm{CC}$ are generated using the generator option. For a detailed description of GCM downscaling by LARS-WG, reference can be made to Semenov \& Barrow (1997).

CFSR daily climate data (1979-2008) at a station within a sub-basin were used for bias correcting the LARS-WG model. The model was then validated by generating weather data of the same time span (baseline data) and comparing its statistical characteristics with the CFSR data. The GCM projected difference in the average monthly precipitation and temperature between the 2020s (2011-2030) and 2050s (2046-2065) and the baseline (1979-2008) periods were computed. These average monthly climate changes were then added to the generated baseline weather data for a station to represent future climate conditions. LARS-WG is a station-specific tool and hence these downscaling processes were done for each of the climate stations in the basin.

\section{Projected future changes in streamflow}

The calibrated SWAT model was forced to simulate flows with the generated meteorological variables over the future periods and in the baseline period. The simulated streamflows corresponding to nine climate modelling chains derived from the MPEH5 and HADCM3 for the A1B and B1 scenarios and future periods of 2020s and 2050s were compared to the simulated baseline streamflow and their differences were computed to represent future changes in streamflow.

\section{RESULTS AND DISCUSSION}

\section{Sensitivity analysis}

The results of the sensitivity analysis for the White Volta basin are presented in Figure 3. The y-axis represents the relative sensitivity (the average change in flow resulting

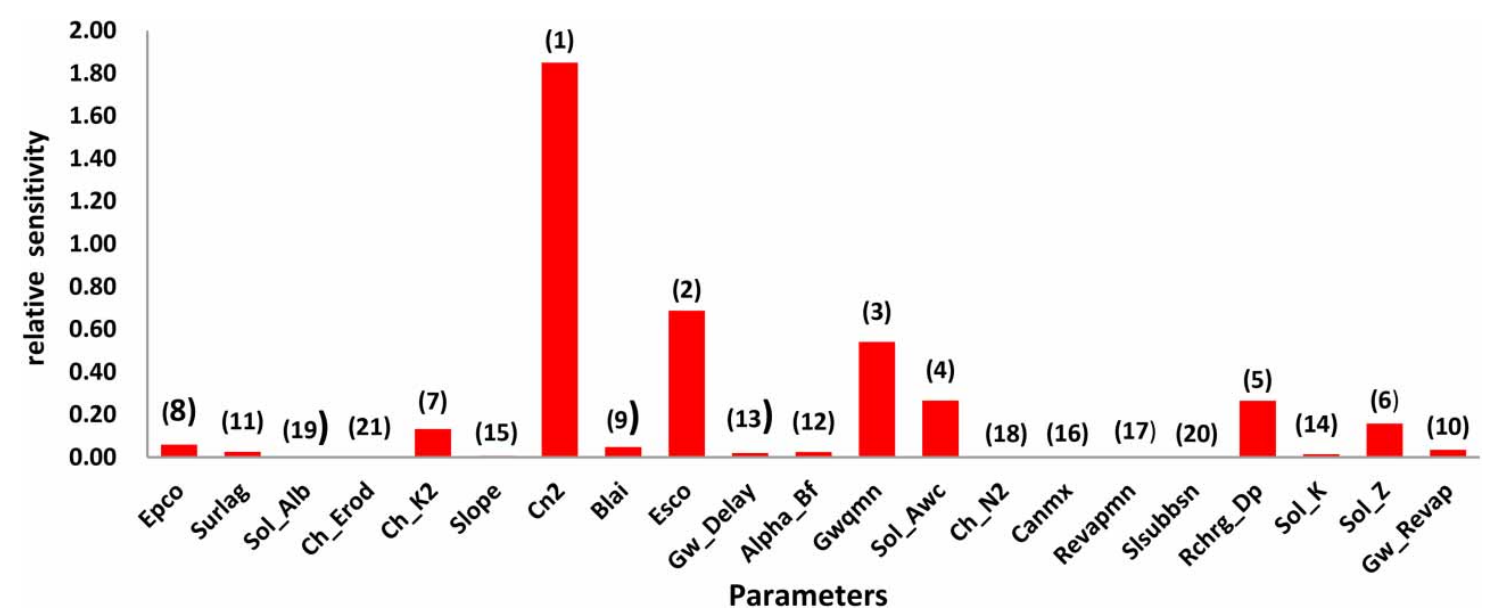

Figure 3 | Sensitivity analysis results. 
from changes in each model parameter), and the numbers in brackets represent the sensitivity ranking. Fourteen of the 21 parameters analysed were found to be more sensitive to the output of SWAT in the basin.

The most sensitive input parameter for the White Volta basin was the SCS runoff curve number $(\mathrm{Cn} 2)$ followed by the soil evaporative compensation factor (Esco) and threshold water depth in the shallow aquifer for return flow to occur (Gwqmn). The two most sensitive parameters, i.e., $\mathrm{Cn} 2$ and Esco are in agreement with sensitivity analysis results of previous studies by Awotwi et al. (2015) and Kankam-Yeboah et al. (20I3) in the White Volta basin. The $\mathrm{Cn} 2$ determines the amount of precipitation that becomes runoff and the amount that infiltrates, Esco is used for modifying the depth distribution to meet soil evaporative demand and accounts mainly for the effect of capillary action and Gwqmn is used for regulating return flow

Table 2 | Final parameter values of the 14 most sensitive parameters during calibration

\begin{tabular}{lll} 
Parameter & Lower and upper bounds & Fitted values \\
\hline Cn2 & \pm 25 & 13.200 \\
Esco & $0-1$ & 0.423 \\
Gwqmn & $\pm 1,000$ & 510.530 \\
Sol_Awc & \pm 25 & 5.480 \\
Rchrg_Dp & $0-1$ & 0.760 \\
Sol_Z & \pm 25 & -0.002 \\
Ch_K2 & $0-150$ & 85.985 \\
Epco & $0-1$ & 0.607 \\
Blai & $0-1$ & 0.372 \\
Gw_Revap & \pm 0.036 & -0.022 \\
Surlag & $0-10$ & 0.634 \\
Alpha_Bf & $0-1$ & 0.351 \\
Gw_Delay & \pm 10 & 4.100 \\
Revapmn & \pm 100 & 58.104 \\
\hline
\end{tabular}

Table 3 | Model performance during calibration and validation periods

\begin{tabular}{|c|c|c|c|c|c|c|c|}
\hline \multirow[b]{2}{*}{ Period } & \multicolumn{2}{|c|}{ Average obs. flow $\left(\mathrm{m}^{3} / \mathrm{s}\right)$} & \multicolumn{2}{|c|}{ Standard deviation $\left(\mathrm{m}^{3} / \mathrm{s}\right)$} & \multicolumn{3}{|c|}{ Model performance } \\
\hline & obs. & sim. & obs. & Sim. & NSE & $\mathbf{R}^{2}$ & PBIAS \\
\hline Calibration (1987-1991) & 314.6 & 286.0 & 506.8 & 392.7 & 0.74 & 0.76 & $-11.0 \%$ \\
\hline Validation (1992-1996) & 269.9 & 247.0 & 445.6 & 380.1 & 0.73 & 0.74 & $-8.6 \%$ \\
\hline
\end{tabular}

(Neitsch et al. 2009). The 14 most sensitive model input parameters determined from the sensitivity analysis were optimised in the calibration.

\section{Calibration and validation}

The main aim of calibration was to adjust the input parameters to obtain the best fit between the observed and simulated streamflows. The 14 most sensitive parameters optimized during calibration and their fitted values are summarized in Table 2. The parameter ranges and final fitted parameter values are in agreement with previous studies in the WA sub-region and White Volta River basin (Schuol et al. 2008; Kankam-Yeboah et al. 2013; Sood et al. 2013).

The simulated streamflow (Table 3) showed 9.10\% and $8.60 \%$ underestimation for both the calibration and validation periods, respectively, compared to the average observed monthly streamflow. The flow hydrographs (Figure 4) also exhibited discrepancies in the peak timings.

Similar calibration issues were faced by Awotwi et al. (2015), Kankam-Yeboah et al. (2013), Schuol \& Abbaspour (2006), Schuol et al. (2008) and Sood et al. (2013) when they applied SWAT model to the basin. Some of the reasons for this are: (a) the model was forced with CFSR data, which might differ from the observed ones; (b) limitations in quality observed flow data, lack of management practices in agricultural land-use information and non-inclusion of dams, reservoirs and ponds in the model; (c) although the model was set up using 2007 land use map, the model was calibrated for 1987-1991, and there is a probability that land cover has changed significantly between these periods and this is likely to affect the calibration results; and (d) underestimation of the streamflow might be as a result of baseflow underestimation which could be due to more than one aquifer contributing to baseflow in the basin, a situation which is not handled in SWAT 2009. 

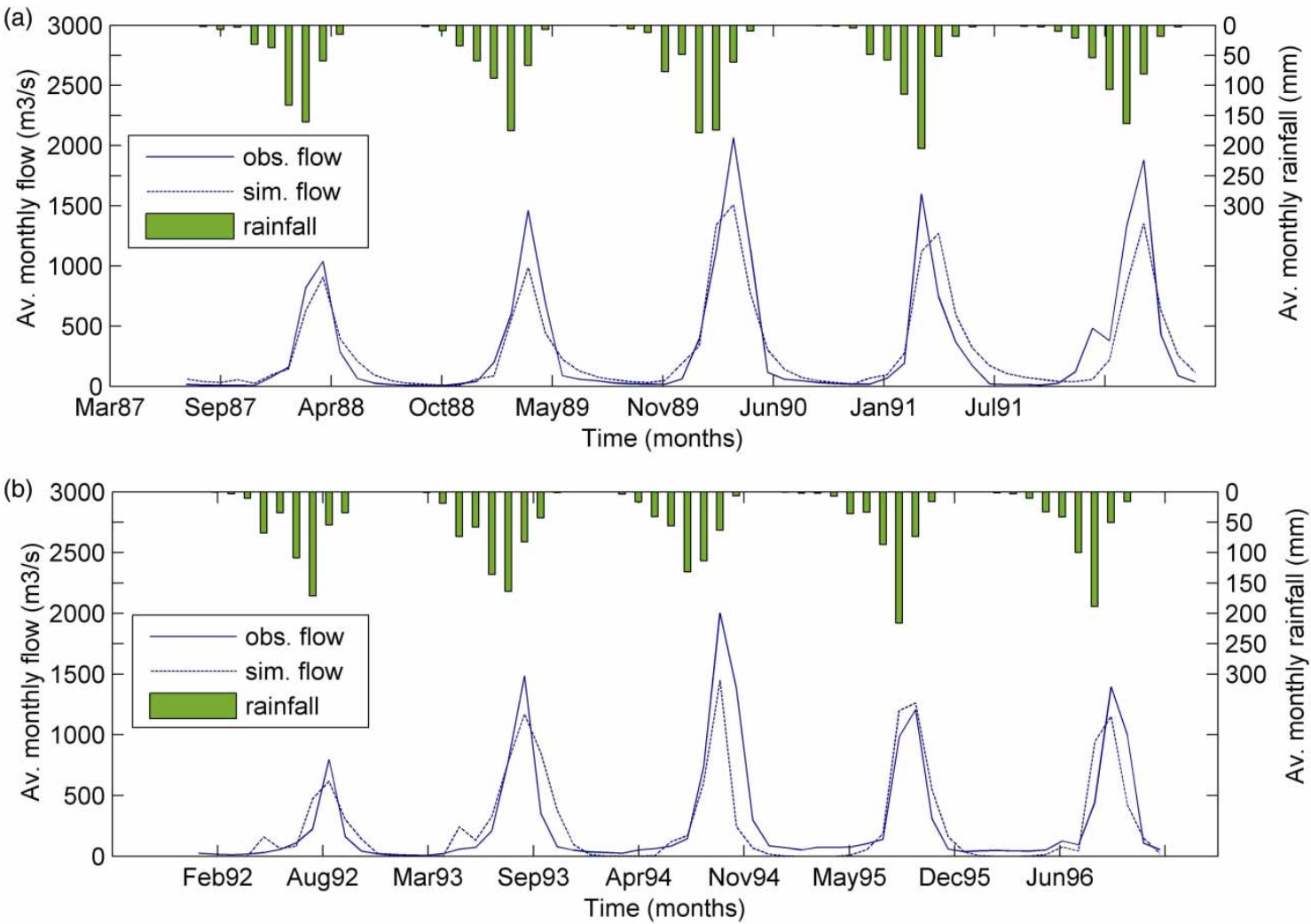

Figure 4 | Monthly discharge during (a) calibration and (b) validation.

A comparison of the hydrographs (Figure 4) and model performance (Table 3) shows that the performance measures $\mathrm{R}^{2}$ and NSE were greater than 0.70 for both the calibration and validation periods. PBIAS was within $\pm 25 \%$, i.e., $-11.0 \%$ and $-8.6 \%$ for calibration and validation periods, respectively.

These indicate good correlation between the monthly observed and simulated streamflow which is a clear indication that the runoff in the basin is well reproduced by the model.

\section{Validation of the LARS-WG downscaling model}

The performance of LARS-WG in simulating CFSR (rainfall, minimum and maximum temperatures) (Figure 5) was assessed using t-test, F-test and chi-square goodness-of-fit test. Each test shows whether the two sets follow the same distribution.

The average $p$ values between CFSR and LARS-WG for the three tests for simulated rainfall, minimum and maximum temperatures were $0.989,1.000$ and 0.998 , respectively. This shows satisfactory reproduction of the CFSR (rainfall, minimum and maximum temperatures) indicating minimum model biases and errors.

\section{Climate projections}

Projections of future changes in climate were determined from outputs of two GCMs, HADCM3 and MPEH5 (ECHAM5), for two CC scenarios, A1B and B1, for two future time periods, 2011-2030 representing the 2020s and 2046-2065 representing the 2050s. The future changes in climate (Tables 4 and 5) represent the difference between the mean precipitation and temperature, respectively, in the future and the baseline period (1979-2008) for the White Volta basin. For this analysis, H represents HADCM3 GCM, M represents MPEH5 GCM and A1B and B1 represent the CC scenarios. For illustration, H2020A1B represents climate conditions in the 2020 s projected by the HADCM3 GCM under the A1B scenario. 


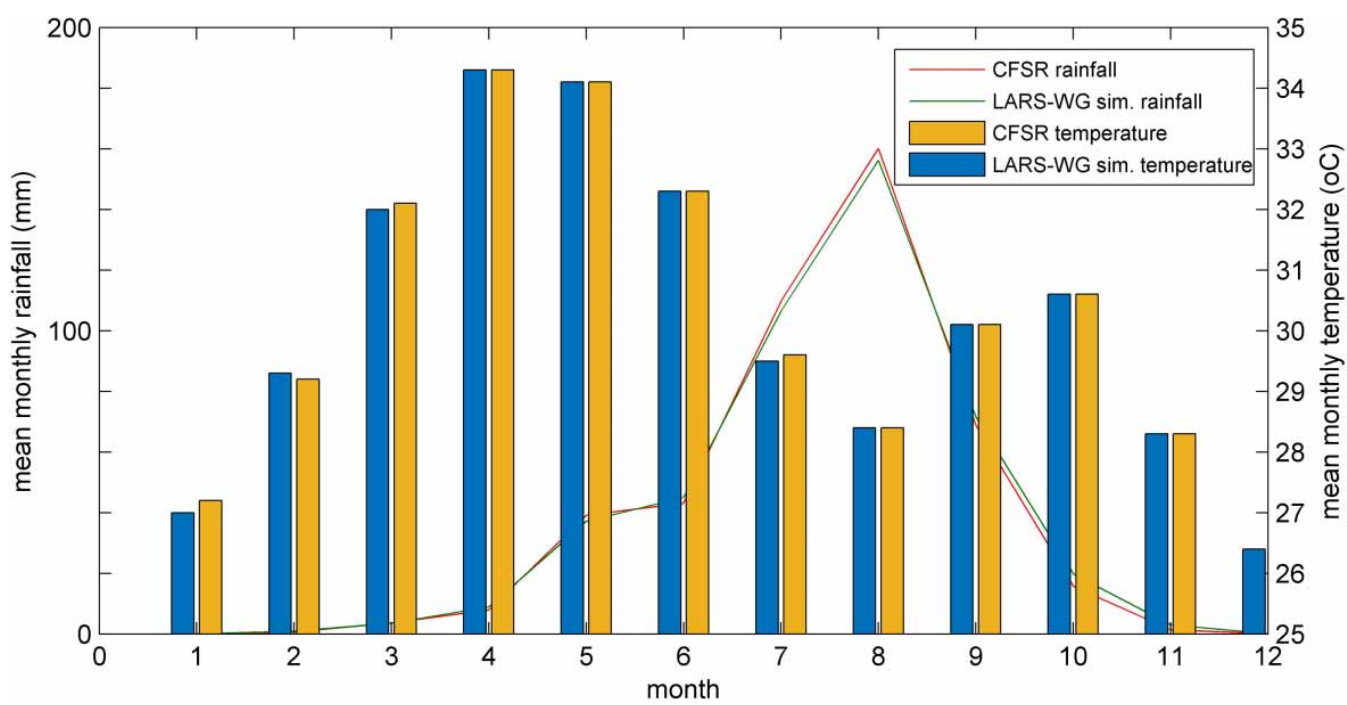

Figure 5 | Comparison of CFSR and LARS-WG simulated rainfall and temperature for the period of 1979-2008.

Table 4 | Annual and monthly mean temperature changes (\%) under different modelling chains for the White Volta basin

\begin{tabular}{|c|c|c|c|c|c|c|c|c|c|c|c|c|c|}
\hline \multirow[b]{2}{*}{ Scenario } & \multicolumn{12}{|c|}{ Month } & \multirow[b]{2}{*}{ Annual } \\
\hline & 1 & 2 & 3 & 4 & 5 & 6 & 7 & 8 & 9 & 10 & 11 & 12 & \\
\hline H2020A1B & 2.81 & 2.47 & 1.97 & 1.57 & 1.44 & 1.53 & 1.36 & 0.94 & 1.45 & 2.2 & 2.97 & 3.30 & 2.00 \\
\hline M2020A1B & 2.30 & 2.20 & 1.97 & 1.86 & 2.00 & 2.03 & 1.67 & 1.26 & 1.22 & 1.55 & 2.00 & 2.31 & 1.86 \\
\hline H2020B1 & 2.40 & 2.10 & 1.97 & 1.92 & 1.80 & 1.78 & 1.33 & 1.33 & 1.25 & 1.28 & 1.93 & 2.70 & 1.82 \\
\hline M2020B1 & 2.08 & 2.30 & 2.06 & 1.83 & 1.65 & 1.60 & 1.30 & 1.23 & 1.06 & 1.15 & 1.29 & 1.59 & 1.60 \\
\hline H2050A1B & 8.49 & 6.73 & 5.54 & 5.11 & 5.34 & 5.89 & 5.62 & 4.76 & 5.18 & 6.58 & 8.62 & 9.90 & 6.48 \\
\hline M2050A1B & 6.59 & 6.33 & 5.98 & 5.90 & 6.07 & 5.95 & 5.35 & 4.52 & 4.23 & 5.10 & 6.44 & 6.98 & 5.79 \\
\hline H2050B1 & 6.63 & 5.18 & 4.28 & 4.18 & 4.48 & 4.41 & 3.78 & 3.71 & 3.99 & 4.77 & 6.36 & 7.67 & 4.95 \\
\hline M2050B1 & 6.12 & 5.92 & 5.39 & 4.88 & 4.78 & 4.73 & 4.53 & 4.24 & 3.90 & 4.31 & 5.18 & 5.84 & 4.98 \\
\hline
\end{tabular}

Table 5 | Annual and monthly precipitation changes (\%) under different modelling chains for the White Volta basin

\begin{tabular}{|c|c|c|c|c|c|c|c|c|c|c|c|c|c|}
\hline \multirow[b]{2}{*}{ Scenario } & \multicolumn{12}{|c|}{ Month } & \multirow[b]{2}{*}{ Annual change } \\
\hline & 1 & 2 & 3 & 4 & 5 & 6 & 7 & 8 & 9 & 10 & 11 & 12 & \\
\hline H2020A1B & 0.00 & 0.0 & 0.94 & -0.30 & -1.24 & 4.90 & 13.64 & -2.92 & 1.30 & -1.50 & 0.00 & 0.00 & 2.97 \\
\hline M2020A1B & 0.00 & 1.96 & 2.50 & -0.20 & -2.31 & -3.79 & -3.56 & 0.68 & 0.98 & -0.50 & -0.63 & 0.00 & -1.13 \\
\hline H2020B1 & 0.00 & 0.00 & 0.31 & 0.30 & 0.39 & 1.32 & 8.31 & 6.73 & 5.41 & 1.06 & -0.63 & 0.00 & 5.40 \\
\hline M2020B1 & 0.00 & 0.00 & 0.31 & 0.59 & -0.39 & -1.79 & -0.31 & -3.29 & 0.30 & -1.50 & -1.25 & 0.00 & -1.43 \\
\hline H2050A1B & 0.00 & 0.00 & 1.25 & -0.69 & -2.59 & 3.60 & 13.38 & 0.99 & 3.67 & -0.50 & 0.00 & 0.00 & 4.36 \\
\hline M2050A1B & 0.00 & 0.00 & 0.94 & 0.00 & -3.71 & -1.71 & 2.12 & 8.69 & 6.37 & 4.79 & 0.63 & 0.00 & 4.10 \\
\hline H2050B1 & 0.00 & 0.00 & 0.31 & 0.49 & 1.43 & 3.40 & 11.49 & 8.81 & 2.39 & -3.39 & -0.63 & 0.00 & 6.64 \\
\hline M2050B1 & 0.00 & 1.96 & 2.81 & 0.00 & -1.92 & -2.84 & 1.65 & 3.03 & 3.47 & 0.39 & -1.25 & 0.00 & 1.52 \\
\hline
\end{tabular}


The analysis of temperature change (Table 4 and Figure 6) shows an increase in the future. Annual average temperature increase ranges from $1.60 \%$ to $2.00 \%$ in the 2020 s and $4.98 \%$ to $6.48 \%$ for the 2050 s. Increase in temperature at monthly time step across the modelling chains showed more uncertainty with ranges of $1.20 \%$ to $2.50 \%$ in the $2020 \mathrm{~s}$ and $4.30 \%$ to $7.60 \%$ in the $2050 \mathrm{~s}$. Further analysis (Figure 6) revealed that the A1B scenario projected higher temperatures than B1 in both the 2020s and 2050s.

Under the same CC scenario, HADCM3 projected higher temperatures than MPEH5 for both the A1B and B1 scenarios in the 2020s but projected higher temperatures than MPEH5 for the A1B scenario but slightly lower temperatures than MPEH5 for B1 scenario in the 2050s. The projected changes indicate that temperature will become warmer in future.

The monthly and annual mean precipitation change values are listed in Table 5. Higher uncertainty in precipitation is projected for the 2050s than the 2020s. All modelling chains (Figure 7) projected more precipitation in the 2050s than in the 2020s, with an average increase of $1.45 \%$ in the $2020 \mathrm{~s}$ and $4.20 \%$ in the 2050 s. Concerning the sign of change and amplitude at monthly time step, there were different trends. In general, MPEH5 projected relatively lower monthly precipitation change, while HADCM3 projected a higher change in precipitation patterns. Precipitation changes at monthly and annual time steps showed more uncertainties in the 2020s than in the 2050s. Monthly precipitation uncertainties were $-0.89 \%$ to $4.52 \%$ in the $2020 \mathrm{~s}$ and $-0.63 \%$ to $1.21 \%$ in the $2050 \mathrm{~s}$. For annual, they were $-1.43 \%$ to $5.4 \%$ for the 2020 s and $1.52 \%$ to $4.36 \%$ for the 2050 s. HADCM3 projected annual precipitation increases in both the 2020s and 2050s while MPEH5 projected a decrease in the 2020s but an increase in the 2050s. Under the same CC scenario, HADCM3 projected a higher annual precipitation increase than MPEH5 in both the 2020s and 2050s. Further analysis revealed that B1 scenario projected higher annual precipitation uncertainty than A1B in both the 2020s and 2050s across the modelling chains.

In the 2020s, the projected precipitation changes ranged from $1.20 \%$ to $2.50 \%$ in the wet season (April to October) and from $-0.17 \%$ to $1.50 \%$ in the dry season (November to March). In the 2050s, the projected precipitation changes ranged from $4.30 \%$ to $7.60 \%$ in the wet
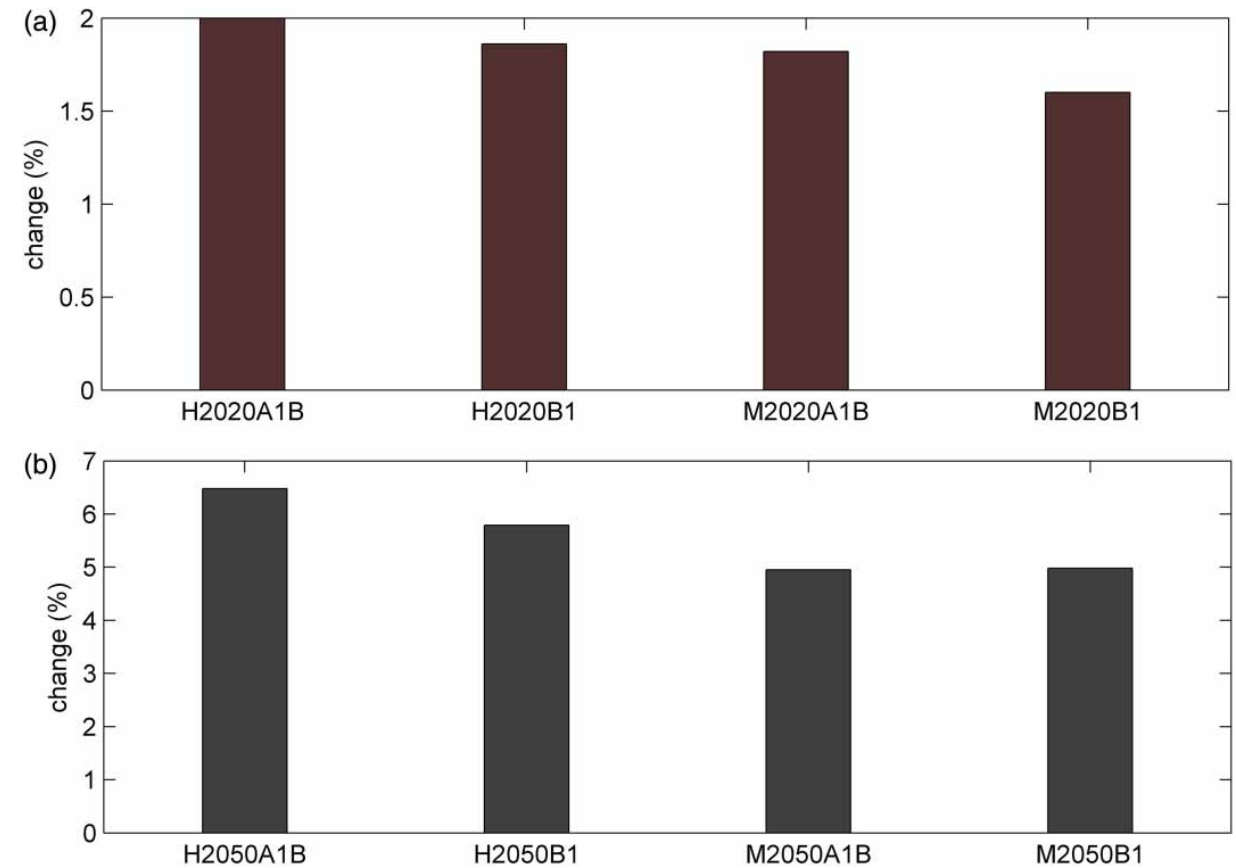

Figure 6 | Annual temperature change in (a) the 2020s and (b) the 2050s. 

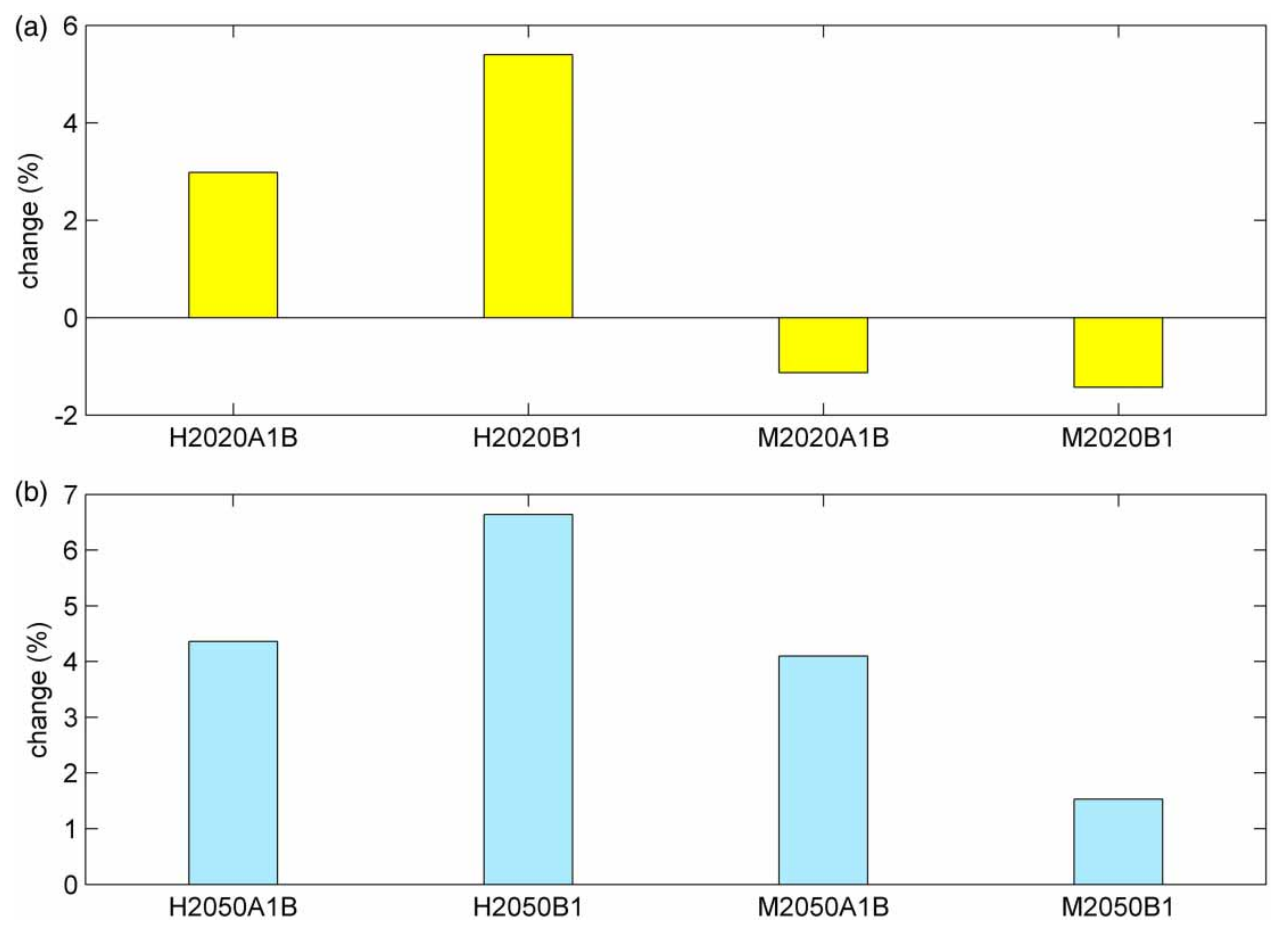

Figure 7 | Average annual precipitation change in (a) the 2020s and (b) the 2050 s.

season and from $0.00 \%$ to $1.51 \%$ in the dry season. Further analysis revealed that HADCM3 B1 scenario projected no change in future dry season precipitation while MPEH5 B1 scenario projected a decrease in the 2020 s and an increase in the 2050s. Overall, the projected seasonal precipitation changes were not so dramatic (within $-0.20 \%$ to $7.00 \%)$.

All modelling chains project the effective rainfall in the White Volta basin to start later in the year (i.e., May rather than April) and the peak of rainfall to shift from September to August. Thus, the rainfall season would be effectively shortened. This might have a significant impact on agriculture. This finding is in agreement with previous studies (Van de Giesen et al. 2010; Sood et al. 2013).

In the 2020s, average annual projection for B1 scenario is $2.00 \%$ compared to $0.92 \%$ for A1B while in the $2050 \mathrm{~s}$, projection for B1 scenario is $4.08 \%$ compared to $4.23 \%$ for A1B. Unlike temperature changes, precipitation changes show much uncertainty under different GCMs and different CC scenarios.

These uncertainties might be due to: first, climate model and emission scenario uncertainties. Uncertainties in CC projections increase with length of time horizon. According to Jenkins \& Lowe (2003), in the near future (the 2020s), climate model uncertainties play the most important role; while over longer time horizons, uncertainties due to selection of emissions scenario become increasingly significant; second, the complexity of the monsoonal system of WA is most likely due to the lack of the influence of land-surface changes in the climate simulations (Jung 2006).

\section{Streamflow response to climate change}

\section{Annual streamflow change}

Figure 8 shows the effect of possible future climate change on annual streamflow.

Flow projections differ across modelling chains in magnitude and sign in the 2020s. While HADCM3 projected an increase, MPEH5 projected a slight decrease. However, there is a consensus that average streamflow will increase by the mid-21st century. Annual streamflow change is projected to range between $-4.00 \%$ to $+13.00 \%$ in the 2020 s and $+3 \%$ to $+16 \%$ in the 2050 s. All modelling chains project 

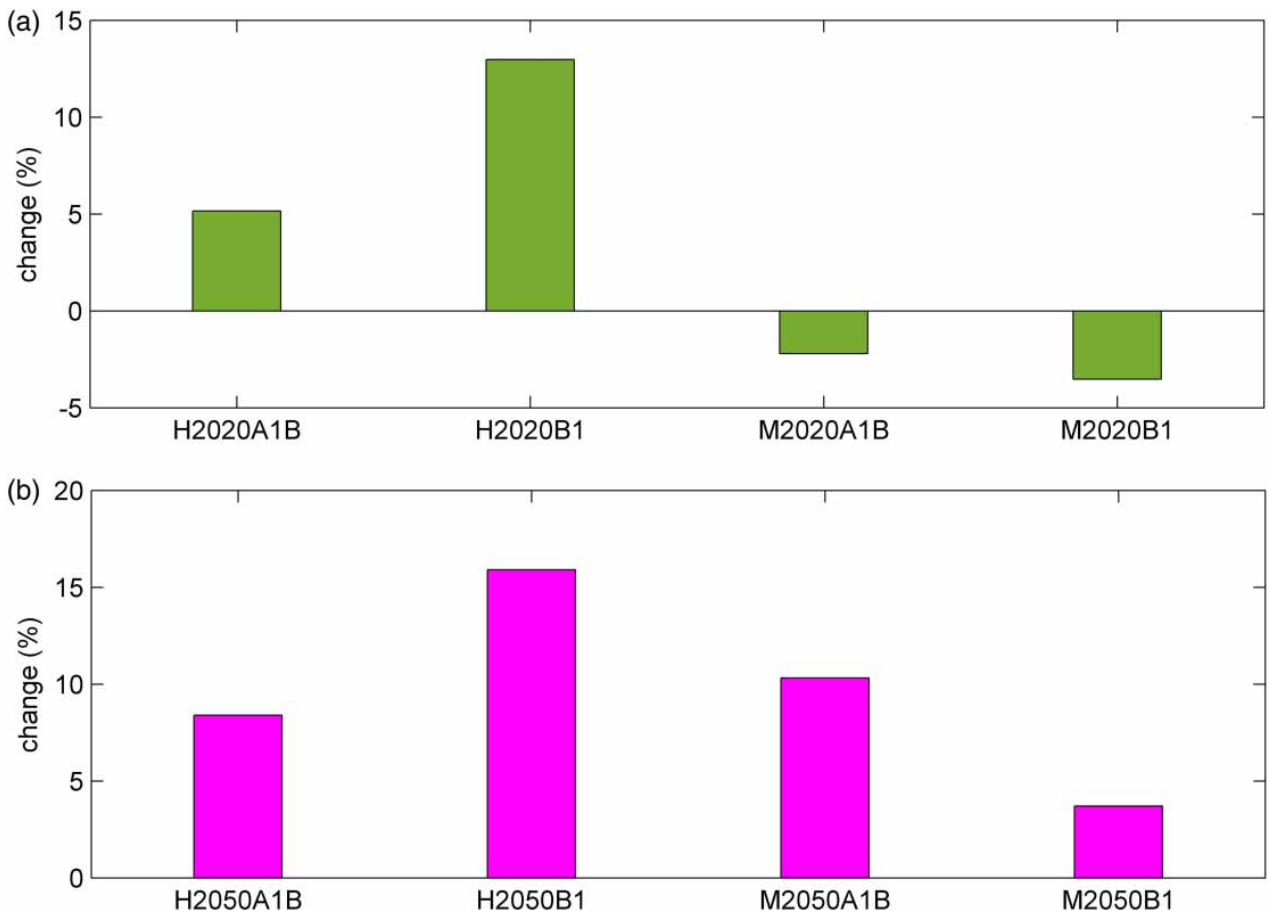

Figure 8 Average annual streamflow change in (a) the 2020s and (b) the 2050s.

higher annual average streamflows in the 2050s than in the 2020s.

Further analysis of future runoff changes in the northern sub-basins $(1,2,3,4,5,6,7$ and 8$)$ and southern sub-basins $(9,10,11,12,13$ and 14) (Figure 9 and Table 6) show similar trends as that of annual streamflow changes for the entire basin. The projections differ across modelling chains in magnitude and sign in the 2020s with HADCM3 projecting an increase in both parts of the basin while MPEH5 projected a decrease. However, both GCMs agree on an increase by mid-21st century. Annual average runoff changes are projected to be more in the southern compared to northern parts of the basin in the 2020s. In the 2050s, the A1B scenario projects higher changes in southern than northern parts of the basin; HADCM3 B1 scenario projects higher changes for southern than northern while the reverse is projected by MPEH5 B1 scenario. Runoff changes in northern parts of the basin are projected to range between $-2.20 \%$ to $+11.50 \%$ and $+4.10 \%$ to $8.70 \%$, while those in the southern parts are $-5.70 \%$ to $+10.30 \%$ and $+3.70 \%$ to $16.20 \%$ in the 2020 s and 2050 s, respectively. The projected decrease in runoff by MPEH5 in the 2020s in both parts of the basin might have dire consequences, especially in the semi-arid north which already has water scarcity.

\section{Monthly streamflow change}

Figure 10 shows monthly streamflow volume changes for the different climate conditions. Monthly streamflow changes show much higher uncertainties compared to the annual ones, with monthly average uncertainties of $-12.50 \%$ to $+31.49 \%$ in the $2020 \mathrm{~s}$ and $-12.50 \%$ to $+29.79 \%$ in the 2050 s compared to annual changes of $-2.21 \%$ to $+12.97 \%$ in the 2020 s and $+3.71 \%$ to $15.90 \%$ in the 2050s.

In the 2020s and 2050s, January, February and December showed no average change while the projected streamflow changes in March, April, May, June, July, August, September, October and November ranged between $-13.00 \%$ to $+32.00 \%$ and $-12.50 \%$ to $+30.00 \%$ in the 2020s and 2050s, respectively. Different modelling chains projected differences in stream flow volumes. For example, the $\mathrm{H} 2050 \mathrm{~A} 1 \mathrm{~B}$ projected $\mathrm{a}+8.12 \%$ increase in streamflow 

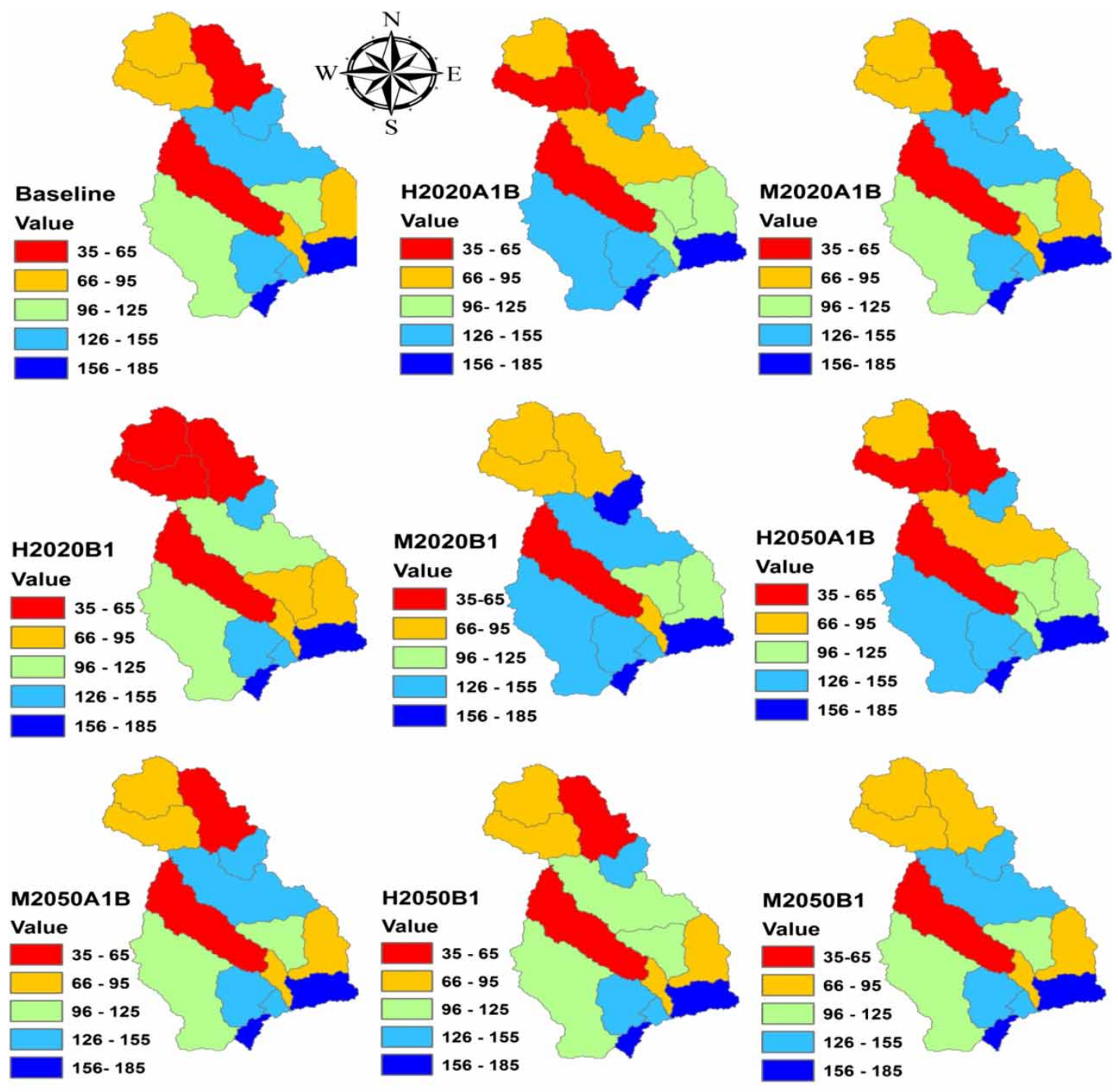

\section{$\begin{array}{lllll}0 & 55110 & 220 & 330 & 440 \\ & & \end{array}$}

Figure 9 | Projected spatial average annual runoff distribution ( $\mathrm{mm})$ across modelling chains.

in June while the M2050B1 projected a $-6.96 \%$ decrease and $\mathrm{H} 2050 \mathrm{~B} 1$ projected a $-4.89 \%$ decrease in streamflow in October while the M2050A1B projected a $+10.18 \%$ increase. A shift in monthly maximum streamflow from September to August is projected by all the modelling chains, while the driest months (December, January and February) will show no change in future. From the results of this analysis, it is evident that projected future monthly streamflow changes for most months would be within $-13.00 \%$ to $+32.00 \%$.

\section{Seasonal streamflow change}

Figure 11 shows the seasonal streamflow change resulting from the modelling chains. In general, the projected streamflow changes for the two seasons exhibit different trends. In the 2020s, the projected streamflow changes ranged from $-3.52 \%$ to $+13.06 \%$ in wet season and from $-1.74 \%$ to $+1.82 \%$ in the dry season. In the 2050 s, projected streamflow changes ranged from $+3.73 \%$ to $16.00 \%$ in wet season and from $0.00 \%$ to $2.00 \%$ in the dry season. 
Table 6 Projected average changes (\%) in annual runoff in northern and southern catchments

\begin{tabular}{lll} 
Modelling chain & $\begin{array}{l}\text { Northern } \Delta \text { Annual } \\
\text { runoff }(\%)\end{array}$ & $\begin{array}{l}\text { Southern } \Delta \text { Annual } \\
\text { runoff }(\%)\end{array}$ \\
\hline H2020A1B & 2.67 & 10.23 \\
M2020A1B & -1.46 & -3.52 \\
H2020B1 & 11.49 & 16.82 \\
M2020B1 & -2.21 & -5.77 \\
H2050A1B & 5.00 & 15.18 \\
M2050A1B & 8.63 & 13.94 \\
H2050B1 & 14.58 & 19.61 \\
M2050B1 & 4.12 & 3.72 \\
\hline
\end{tabular}

HADCM3 B1 modelling chain projects no change in dry season streamflow volume. The magnitude and sign of the seasonal streamflow changes show significant uncertainties among different modelling chains. With the exception of the M2020A1B and M2020B1 modelling chains, the magnitude and sign of change in streamflow volume in the wet season are higher compared to that of the dry season. This might be due to the projected higher rainfall in the wet season than the dry season.
Dry season streamflow shows higher changes for A1B compared to B1 scenario for all modelling chains while wet season streamflow shows higher changes for B1 than A1B in the 2020s. In the 2050s, H2050B1 projects higher wet season streamflow changes than H2050A1B while a higher change is projected by M2050A1B compared to M2050B1. In the 2020s, the average dry season streamflow change for $\mathrm{A} 1 \mathrm{~B}$ is $1.68 \%$ compared to $-0.87 \%$ for $\mathrm{B} 1$ while for wet season, it is $1.49 \%$ for $\mathrm{A} 1 \mathrm{~B}$ compared to $4.77 \%$ for $\mathrm{B} 1$. In the $2050 \mathrm{~s}$, dry season changes are $4.55 \%$ for A1B compared to $1.00 \%$ for B1; for wet season, it is 9.15\% for A1B compared to $9.87 \%$ for B1. It is also noted that while dry season streamflow volume decreases in M2020B1, it increases in M2050B1. Overall, the projected seasonal streamflow changes were not so dramatic (within $-4.00 \%$ to $+17.00 \%)$.

\section{Comparison of study results with previous studies}

The results of this study and similar previous studies carried out in the Volta and White Volta basins are shown in Table 7 .
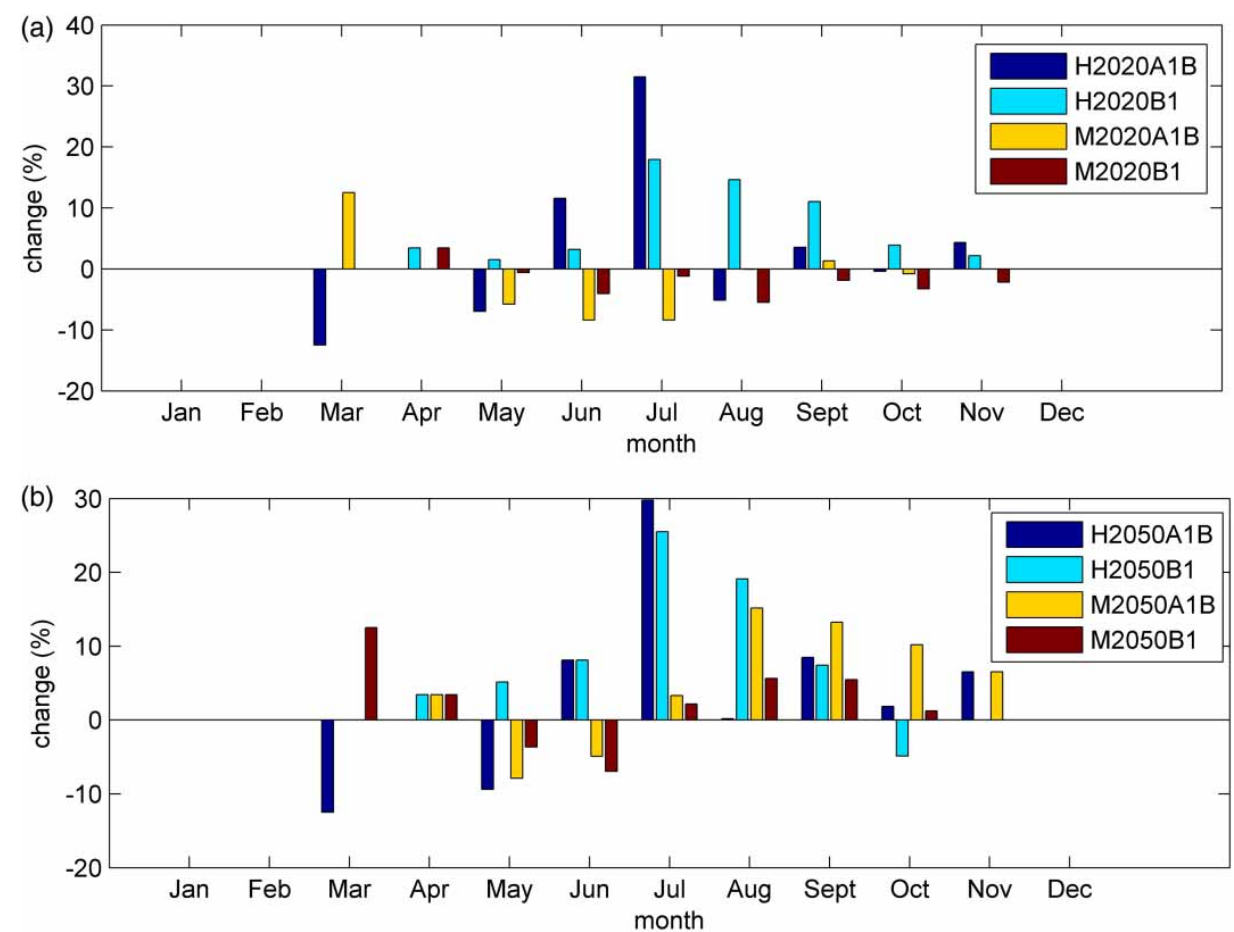

Figure 10 | Monthly streamflow volume change in (a) the 2020s and (b) the 2050s. 

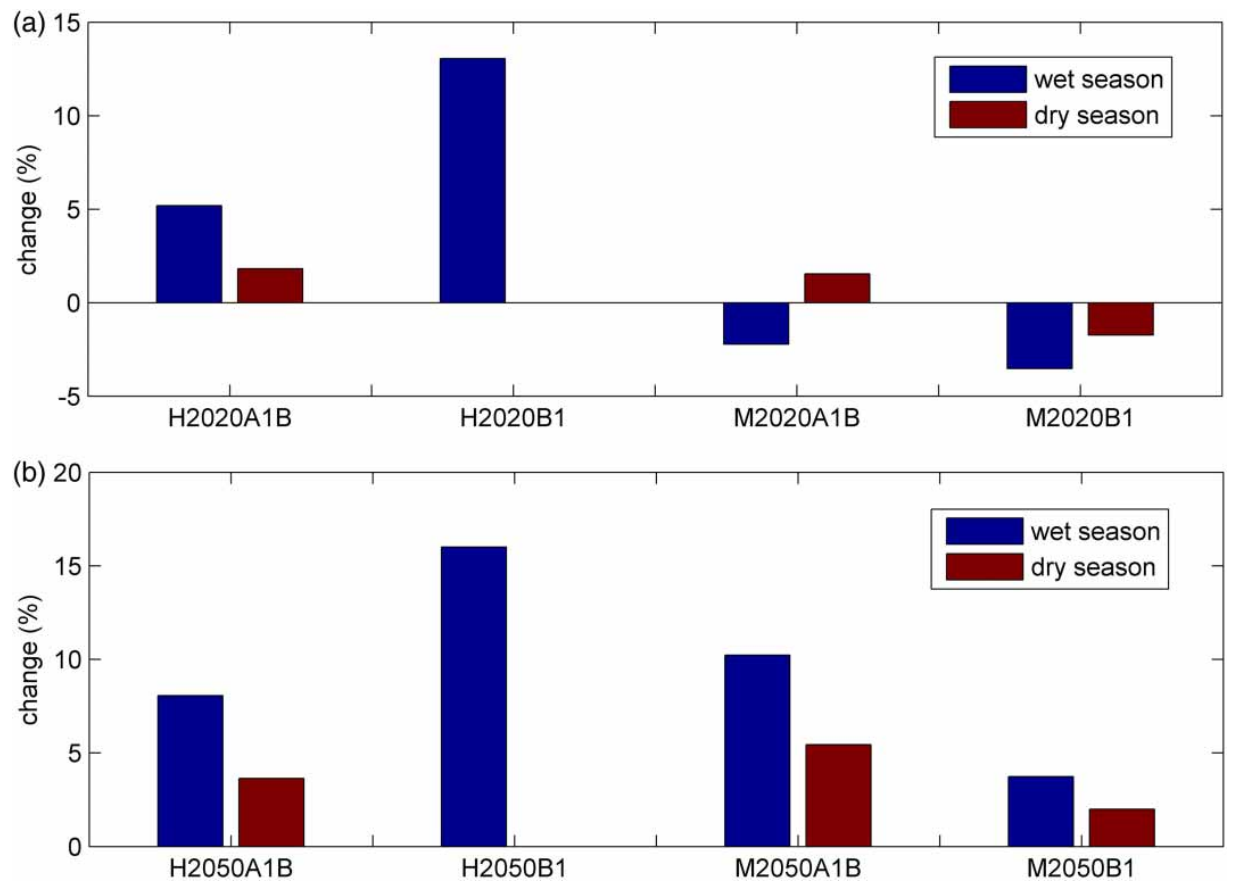

Figure 11 | Seasonal streamflow change in (a) the 2020s and (b) the 2050s.

Table 7 Results of this study and previous studies

\begin{tabular}{|c|c|c|c|c|c|c|c|}
\hline Source & River & $\begin{array}{l}\text { Target } \\
\text { period }\end{array}$ & $\begin{array}{l}\text { Hydrologic } \\
\text { model }\end{array}$ & $\begin{array}{l}\text { Climate } \\
\text { model }\end{array}$ & Scenario & $\begin{array}{l}\Delta \text { Annual } \\
\text { rainfall (\%) }\end{array}$ & $\begin{array}{l}\Delta \text { Annual } \\
\text { streamflow (\%) }\end{array}$ \\
\hline Study & White Volta & $2011-2030$ & SWAT & HADCM3 & A1B & 3.0 & 5.2 \\
\hline Study & White Volta & $2011-2030$ & SWAT & HADCM3 & $\mathrm{B} 1$ & 5.4 & 13.0 \\
\hline Study & White Volta & 2046-2065 & SWAT & HADCM3 & A1B & 4.4 & 8.4 \\
\hline Study & White Volta & 2046-2065 & SWAT & HADCM3 & B1 & 6.6 & 15.9 \\
\hline Study & White Volta & $2011-2030$ & SWAT & MPEH5 & A1B & -1.1 & -2.2 \\
\hline Study & White Volta & $2011-2030$ & SWAT & MPEH5 & $\mathrm{B} 1$ & -1.4 & -3.6 \\
\hline Study & White Volta & 2046-2065 & SWAT & MPEH5 & A1B & 4.1 & 10.3 \\
\hline Study & White Volta & 2046-2065 & SWAT & MPEH5 & $\mathrm{B} 1$ & 1.5 & 3.7 \\
\hline Andah et al. (2003) & Volta & 2020-2039 & WEAP & HADCM3 & $\mathrm{A} 2$ & 8.0 & 27.0 \\
\hline Andah et al. (2003) & Volta & 2020-2039 & WEAP & HADCM3 & B2 & 10.0 & 34.0 \\
\hline Andah et al. (2003) & Volta & 2070-2099 & WEAP & HADCM3 & $\mathrm{A} 2$ & 6.0 & 13.0 \\
\hline Andah et al. (2003) & Volta & 2070-2099 & WEAP & HADCM3 & $\mathrm{B} 2$ & 9.0 & 34.0 \\
\hline Obuobie (2008) & White Volta & 2030-2039 & SWAT & ECHAM4-MM5 & IS92a & 6.0 & 33.0 \\
\hline Jung (2006) & Volta & 2030-2039 & WaSIM & ECHAM4-MM5 & IS92a & 5.0 & 17.0 \\
\hline Jung (2006) & White Volta & 2030-2039 & WaSIM & ECHAM4-MM5 & IS92a & 5.0 & 22.3 \\
\hline Kankam-Yeboah et al. (20I3) & White Volta & 2006-2035 & SWAT & ECHAM4-CSIRO & A1F1 & -12.3 & -22.0 \\
\hline Kankam-Yeboah et al. (20I3) & White Volta & $2036-2075$ & SWAT & ECHAM4-CSIRO & A1F1 & -19.6 & -50.0 \\
\hline Awotwi et al. (20I5) & White Volta & 2030-2043 & SWAT & REMO & A1B & 8.0 & 26.0 \\
\hline
\end{tabular}


The increase in the future simulated annual streamflow, as projected by H2020A1B, H2020B1, H2050A1B, H2050B1, M2050A1B and M2050B1 modelling chains in this study for the White Volta basin, depicts similar trends as that obtained for the entire Volta basin in the ADAPT project (Andah et al. 2003). The results of the ADAPT project show an increase in the streamflow for all the future $\mathrm{CC}$ scenarios. The $\mathrm{A} 2$ and $\mathrm{B} 2$ scenarios of the time slice 2020-2039 are of particular interest because of the similarity they have with this study by way of their time slice for 2011-2030 (2020s) and the magnitude of increase in the future streamflows. The ADAPT projected increases in the mean annual streamflow for the A2 and B2 scenarios, respectively, for 2020-2039 is much higher compared to this study.

Another study of interest for comparison purposes is the CC impact studies done by Jung (2006) in the Volta and White Volta basins. The results of the H2020A1B, H2020B1 modelling chains in this study are similar to those obtained by Jung (2006) for Volta and White Volta basins. Both results show increases in streamflow in the near future, i.e., 2011-2030 (study) and 2030-2039 (Jung 2006), respectively. However, the projections by Jung (2006) are much higher compared to this study.

Similarly, the projected annual increases in streamflow by the H2020A1B and H2020B1 modelling chains in this study are similar to those obtained by Awotwi et al. (20I5) for the White Volta basin. Projected increase in the mean annual streamflow by Awotwi et al. (20I5) for 2030-2043 is also much higher compared to 2011-2030 of this study.

The projected annual decreases in streamflow by the M2020A1B and M2020B1 modelling chains in this study agree with those of Kankam-Yeboah et al. (2013) for the White Volta basin. However, projected decrease in the mean annual streamflow by Kankam-Yeboah et al. (2013) for 2006-2035 (2020s) is also much higher compared to the 2020s in this study. Although Kankam-Yeboah et al. (20I3) projected decrease in rainfall and consequently decrease in the streamflow in the White Volta basin in 2036-2075 (2050s), our results projected increase in rainfall and surface runoff in the 2050s for all the different modelling chains.

Possible reasons for the deviations in this study results compared with previous studies with regards to the magnitude and sign of change of the future annual streamflow projections could be due to differences in: (i) the way the future climate series were processed before being used, (ii) hydrological models used, (iii) GCMs used, (iv) emission scenarios used and (v) model calibration periods used.

\section{Policy implications for water storage and water resources management}

The model results project greater climate variability, such as delayed onset of rainfall, shortening of the rainy season, higher temperatures (resulting in increased potential evapotranspiration). These will make farming systems in the basin more highly vulnerable to CC. Famers in the basin have already adopted a wide range of $\mathrm{CC}$ adaptation techniques to increase crop yield (Van de Giesen et al. 20Io). To add to these, agricultural policy strategies must shift towards those which will enable farmers to better utilize the rains in a growing period; such as the planting of rapidly maturing crops, planting crops adapted to the new climate patterns, synchronizing farming calendars to the new rainfall regime and developing new drought and heat-resistant varieties.

Based on the model results, there are uncertainties over the sign of the variation of both precipitation and streamflow in the basin in the 2020s. While HADCM3 projected an increase in runoff in both the northern and southern parts of the basin, MPEH5 projected a decrease. The projected decrease in runoff by MPEH5 in the 2020s might have dire consequences, especially for the semi-arid north which already has water scarcity. To reduce the negative effects of the decreasing water availability, water use efficiency and environmental integrity must be adopted for effective management of water resources in both parts of the basin. Efficient utilization of water will go a long way to reducing demands from the three main water sectors: domestic supply, agriculture and industry. This is a costeffective way of adapting to the decreasing water resources projected for the future in both basins (Kankam-Yeboah et al. 2013). Awareness of the need to maintain environmental integrity and the creation of buffer zones for headwaters, wetlands and river bodies would minimize the pollution and degradation of the basin's water resources due to anthropogenic factors (Kankam-Yeboah et al. 20I3). 
The consensus that average streamflow in the White Volta basin will increase by mid-21st century among all modelling chains will call for appropriate investment in adaptive water management practices that are cost-effective (e.g., small reservoirs) for harvesting runoff water. Water stored in small reservoirs can serve multiple uses (e.g., irrigation, livestock watering and aquaculture). The use of small reservoirs for harvesting runoff is already being practised in the White Volta basin. In the entire Volta basin, there has been an increase in small reservoirs between 1984 and 1999 (Van de Giesen et al. 2010). This increase has halted in Ghana although a couple are undergoing rehabilitation. In Burkina Faso, the construction continues and, currently, the number of small reservoirs is estimated at 2,000 (Van de Giesen et al. 2010). Unfortunately, the reservoirs are designed without considering $\mathrm{CC}$. The designs can be improved with CC considerations. Both Ghana and Burkina Faso have plans to develop large reservoirs purposely for irrigation and hydropower. It would therefore be necessary to increase the storage capacity of both planned and existing reservoirs (e.g., the Bagre Reservoir which is vital for hydropower and irrigation in Burkina Faso) to store more water in wet years to partly offset the difficulties associated with dry years.

A study by Obuobie (2008) in the White Volta basin reveals that annual recharge to the groundwater in the basin is about $7 \%$ of annual rainfall. This figure is expected to increase by about 33\% in future as a result of CC. Geophysical surveys and physico-chemical parameter tests of shallow groundwater by Barry et al. (2010) in the Atankwidi catchment in the White Volta basin reveal higher annual aquifer water storage of approximately $3.7 \times 10^{8} \mathrm{~m}^{3}$, which is more than annual irrigation water demand of $8.9 \times 10^{4} \mathrm{~m}^{3}$, and suitability of the water for both water supply and irrigation. The high value of RCHRG_DP (deep aquifer percolation fraction, i.e., the fraction of percolation from the root zone that recharges the deep aquifer), up to 0.8 in the basin, indicates the potential for harnessing water stored in the deep aquifer. Irrigation using groundwater from both shallow and deep wells could be developed and linked with energy policies, given the importance of energy in sustainable groundwater development.

Therefore, in light of changing climate, there is the need to develop integrated water resource management strategies that consider water storage as a system comprising a range of storage options (Sood et al. 20I3). CC adaptation mechanisms must be incorporated into feasibility studies and projects, and within the broader development context for the basin (Kankam-Yeboah et al. 20r3). Any development within the basin should take into consideration the likely impact of CC on the future hydrology of the basin and make the necessary provisions in planning, design and budgeting.

\section{CONCLUSIONS AND RECOMMENDATIONS}

For this study, a high resolution $\left(0.3^{\circ} \sim 3 \mathrm{~km}\right)$ Climate Forecast System Reanalysis (CFSR), hydrologic model (SWAT) and two IPCC climate change (CC) scenarios (A1B and B1) combined with two global climate models (HADCM3 and MPEH5) downscaled using LARS-WG were used to evaluate the impact of CC on streamflow in the datascarce White Volta River basin of WA.

The model results project greater climate variability, such as later onset of rainfall, shortening of the rainy season and higher temperatures. These will make farming systems in the basin more highly vulnerable to CC.

There was uncertainty over the sign of the variation of both precipitation and streamflow in the basin in the 2020s. While HADCM3 projected an increase in runoff in both the northern and southern parts of the basin, MPEH5 projected a decrease. The projected decrease in runoff by MPEH5 in the 2020s might have dire consequences, especially for the semi-arid north which already has water scarcity.

There was, however, consensus among all climate modelling chains that the White Volta River basin will likely experience an increase in streamflow by mid-21st century. It would call for appropriate investment into cost-effective adaptive water management practices (e.g., runoff water harvesting through small reservoirs) to store more water in wet years to partly offset the difficulties associated with dry years. Agricultural policy strategies must also shift towards those which will enable farmers to better utilize the rains in a growing period. It is also suggested that any development within the basin should take into consideration the likely impact of climate change on the future hydrology of 
the basin and make the necessary provisions in planning, design and budgeting.

While the results of this study are important regarding CC impacts on streamflow, which can serve as crucial input for CC adaptation mechanisms in the White Volta basin, there were three key uncertainties related to it: (a) input data (e.g., climate and discharge data); (b) hydrologic model; and (c) climate model and scenarios. It is therefore recommended that: (a) a more extensive study that involves the use of multiple hydrological models, climate change scenarios and climate models is planned for the near future; (b) more climate and gauging stations be established by the Volta Basin River Authority (VBRA); and (c) proper training of personnel in the measurement, recording and storage of data. These will go a long way to improve the quality of ground observations. In light of changing climate, it is also recommended that water resource management in the basin must be done in an integrated way that considers water storage as a system comprising a range of storage options; this will ensure water security within the basin.

\section{ACKNOWLEDGEMENTS}

This research has been supported by Non-profit Industry Financial Program of Ministry of Water Resources of China (No. 201301066), the National Natural Science Foundation of China (40701024, 41101511, 51409152), and Hubei Provincial Collaborative Innovation Center for Water Security.

\section{REFERENCES}

Akpoti, K., Antwi, E. O. \& Kabo-bah, A. T. 2016 Impacts of rainfall variability, land use and land cover change on stream flow of the black Volta Basin, West Africa. Hydrology 3, 26.

Amisigo, B., Van de Giesen, N., Rogers, C., Andah, W. \& Friesen, J. 2008 Monthly streamflow prediction in the Volta Basin of West Africa: a SISO NARMAX polynomial modelling. Physics and Chemistry of the Earth, Parts $A / B / C$ 33, 141-150.

Andah, W. E., van de Giesen, N. \& Biney, C. A. 2003 Water, Climate, Food, and Environment in the Volta Basin. Adaptation strategies to changing environments.
Contribution to the ADAPT project: http://www weap21 org/downloads/ADAPTVolta pdf

Andreini, M., van de Giesen, N., van Edig, A., Fosu, M. \& Andah, W. 2000 Volta Basin Water Balance. ZEF Discussion Papers on Development Policy. Paper number 21. ZEF, Bonn.

Arnold, J. G., Srinivasan, R., Muttiah, R. S. \& Williams, J. R. 1998 Large area hydrologic modeling and assessment part I: model development. Journal of the American Water Resources Association 34, 73-89.

Awotwi, A., Kumi, M., Jansson, P., Yeboah, F. \& Nti, I. 2015 Predicting hydrological response to climate change in the White Volta catchment, West Africa. Journal of Earth Science \& Climatic Change 6, 1-7.

Barry, B., Kortatsi, B., Forkuor, G., Gumma, M. K., Namara, R. E., Rebelo, L. M., van den Berg, J. \& Laube, W. 2010 Shallow Groundwater in the Atankwidi Catchment of the White Volta Basin: Current Status and Future Sustainability, Vol. 139. IWMI, Colombo.

Berg, A., De Noblet-Ducoudré, N., Sultan, B., Lengaigne, M. \& Guimberteau, M. 2013 Projections of climate change impacts on potential C4 crop productivity over tropical regions. Agricultural and Forest Meteorology 170, 89-102.

CGIAR-CSI 2009 SRTM 90 m Digital Elevation Data. http://srtm. csi.cgiar.org/ (accessed 3 March 2017).

Coffey, R., Benham, B., Kline, K., Wolfe, M. L. \& Cummins, E. 2015 Modeling the impacts of climate change and future land use variation on microbial transport. Journal of Water and Climate Change 6, 449-471.

Conway, D., Persechino, A., Ardoin-Bardin, S., Hamandawana, H., Dieulin, C. \& Mahé, G. 2009 Rainfall and water resources variability in sub-Saharan Africa during the twentieth century. Journal of Hydrometeorology 10, 41-59.

Dile, Y. T. \& Srinivasan, R. 2014 Evaluation of CFSR climate data for hydrologic prediction in data-scarce watersheds: an application in the Blue Nile River Basin. Journal of the American Water Resources Association 50, 1226-1241.

Duan, Q., Sorooshian, S. \& Gupta, V. 1992 Effective and efficient global optimization for conceptual rainfall-runoff models. Water Resources Research 28, 1015-1031.

Fuka, D. R., Walter, M. T., MacAlister, C., Degaetano, A. T., Steenhuis, T. S. \& Easton, Z. M. 2014 Using the Climate Forecast System Reanalysis as weather input data for watershed models. Hydrological Processes 28, 5613-5623.

Gassman, P. W., Reyes, M. R., Green, C. H. \& Arnold, J. G. 2007 The soil and water assessment tool: historical development, applications, and future research directions. Transactions of the ASABE 50, 1211-1250.

Globalweather 2017 NCEP Climate Forecast System Reanalysis (CFRS). http://globalweather.tamu.edu/ (accessed 3 March 2017).

Gyau-Boakye, P. \& Tumbulto, J. 2006 Comparison of rainfall and runoff in the humid south-western and the semiarid northern savannah zone in Ghana. African Journal of Science and Technology 7, 64-72. 
IPCC 2007 The Physical Science Basis: Contribution of Working Group I to the Fourth Assessment Report of the Intergovernmental Panel on Climate Change. Cambridge University Press, Cambridge, UK.

IPCC 2013 Climate Change 2013: The Physical Science Basis. Working Group 1(WG1) Contribution to the Intergovernmental Panel on Climate Change (IPCC) 5th Assessment Report (AR5). Cambridge, UK and New York, USA.

Jenkins, G. \& Lowe, J. 2003 Handling Uncertainties in the UKCIP02 Scenarios of Climate Change. Technical note 44. Hadley Centre, Exeter, UK.

Jung, G. (2006) Regional Climate Change and the Impact on Hydrology in the Volta Basin of West Africa. FZKA. Dissertation, University of Augsburg, Germany.

Jung, G. \& Kunstmann, H. 2007 Modelling Regional Climate Change and the Impact on Surface and Sub-Surface Hydrology in the Volta Basin (West Africa). IAHS Publication 313, pp. 150-157.

Kankam-Yeboah, K., Obuobie, E., Amisigo, B. \& OpokuAnkomah, Y. 2013 Impact of climate change on streamflow in selected river basins in Ghana. Hydrological Sciences Journal 58, 773-788.

Lacombe, G., McCartney, M. \& Forkuor, G. 2012 Drying climate in Ghana over the period 1960-2005: evidence from the resampling-based Mann-Kendall test at local and regional levels. Hydrological Sciences Journal 57, 1594-1609.

Laux, P., Kunstmann, H. \& Bárdossy, A. 2008 Predicting the regional onset of the rainy season in West Africa. International Journal of Climatology 28, 329-342.

Mango, L. M., Melesse, A. M., McClain, M. E., Gann, D. \& Setegn, S. 2oII Land use and climate change impacts on the hydrology of the upper Mara River Basin, Kenya: results of a modeling study to support better resource management. Hydrology and Earth System Sciences 15, 2245-2258.

Milzow, C., Krogh, P. E. \& Bauer-Gottwein, P. 20 II Combining satellite radar altimetry, SAR surface soil moisture and GRACE total storage changes for hydrological model calibration in a large poorly gauged catchment. Hydrology and Earth System Sciences 15, 1729-1743.

Moriasi, D. N., Arnold, J. G., Van Liew, M. W., Bingner, R. L., Harmel, R. D. \& Veith, T. L. 2007 Model evaluation guidelines for systematic quantification of accuracy in watershed simulations. Transactions of the ASABE $\mathbf{5 0}$, 885-900

Morris, M. D. I99I Factorial sampling plans for preliminary computational experiments. Technometrics 33, 161-174.

Nakicenovic, N., Alcamo, J., Grubler, A., Riahi, K., Roehrl, R. A., Rogner, H. H. \& Victor, N. 2000 Special Report on Emissions Scenarios: A Special Report of Working Group III of the Intergovernmental Panel on Climate Change. Cambridge University Press, Cambridge, UK, 599 pp. Available online at: http://www.grida.no/climate/ipcc/emission/index.htm

Nash, J. E. \& Sutcliffe, J. V. I970 River flow forecasting through conceptual models part I - A discussion of principles. Journal of Hydrology 10, 282-290.
Neiland, A. \& Béné, C. 2008 Review of river fisheries valuation in West and Central Africa. In: Tropical River Fisheries Valuation: Background Papers to a Global Synthesis. WorldFish Center, Penang, Malaysia, pp. 47-106.

Neitsch, S. L., Arnold, J. G., Kiniry, J. R. \& Williams, J. R. 2009 Soil and Water Assessment Tool Theoretical Documentation Version 2009. Texas Water Resources Institute. http://hdl. handle.net/1969.1/128050

Obuobie, E. 2008 Estimation of Groundwater Recharge in the Context of Future Climate Change in the White Volta River Basin, West Africa. PhD Thesis, University of Bonn, Germany.

Obuobie, E. \& Diekkrüger, B. 2008 Using SWAT to evaluate climate change impact on water resources in the White Volta River Basin, West Africa. In: Conference on International Research on Food Security, Natural Resource Management and Rural Development, Hohenheim, Germany.

Obuobie, E., Kankam-Yeboah, K., Amisigo, B., Opoku-Ankomah, Y. \& Ofori, D. 2012 Assessment of vulnerability of river basins in Ghana to water stress conditions under climate change. Journal of Water and Climate Change 3, 276-286.

Oguntunde, P. G., Friesen, J., van de Giesen, N. \& Savenije, H. H. 2006 Hydroclimatology of the Volta River Basin in West Africa: trends and variability from 1901 to 2002. Physics and Chemistry of the Earth, Parts $A / B / C$ 31, 1180-1188.

Reichler, T. \& Kim, J. 2008 How well do coupled models simulate today's climate? Bulletin of the American Meteorological Society 89, 303-311.

Roeckner, E., Bauml, G., Bonaventura, L., Brokopf, R., Esch, M., Giorgetta, M. \& Rhodin, A. 2003 The Atmospheric General Circulation Model ECHAM 5. Part I: Model Description. Technical Report No. 349, Max-Planck-Institut für Meteorologie, Hamburg, Germany.

Roudier, P., Ducharne, A. \& Feyen, L. 20I4 Climate change impacts on runoff in West Africa: a review. Hydrology and Earth System Sciences 18, 2789-2801.

Ruelland, D., Ardoin-Bardin, S., Collet, L. \& Roucou, P. 2012 Simulating future trends in hydrological regime of a large Sudano-Sahelian catchment under climate change. Journal of Hydrology 424, 207-216.

Saha, S., Moorthi, S., Pan, H. L., Wu, X., Wang, J., Nadiga, S. \& Liu, H. 2010 The NCEP climate forecast system reanalysis. Bulletin of the American Meteorological Society 91, 1015-1058.

Schuol, J. \& Abbaspour, K. 2006 Calibration and uncertainty issues of a hydrological model (SWAT) applied to West Africa. Advances in Geosciences 9, 137-143.

Schuol, J., Abbaspour, K. C., Srinivasan, R. \& Yang, H. 2008 Estimation of freshwater availability in the West African subcontinent using the SWAT hydrologic model. Journal of Hydrology 352, 30-49.

Semenov, M. A. \& Barrow, E. M. 1997 Use of a stochastic weather generator in the development of climate change scenarios. Climatic Change 35, 397-414.

Snell, S. E., Gopal, S. \& Kaufmann, R. K. 2000 Spatial interpolation of surface air temperatures using artificial 
neural networks: evaluating their use for downscaling GCMs. Journal of Climate 13, 886-895.

Solaymani, H. R. \& Gosain, A. 2015 Assessment of climate change impacts in a semi-arid watershed in Iran using regional climate models. Journal of Water and Climate Change 6, 161-180.

Sood, A., Muthuwatta, L. \& McCartney, M. 2013 A SWAT evaluation of the effect of climate change on the hydrology of the Volta River basin. Water International 38, 297-311.

Stott, P. A., Tett, S., Jones, G., Allen, M., Mitchell, J. \& Jenkins, G. 2000 External control of 20th century temperature by natural and anthropogenic forcings. Science 290, 2133-2137.

Sultan, B., Roudier, P., Quirion, P., Alhassane, A., Muller, B., Dingkuhn, M. \& Baron, C. 2013 Assessing climate change impacts on sorghum and millet yields in the Sudanian and Sahelian savannas of West Africa. Environmental Research Letters 8, 014040.

USDA-SCS 1972 Section 4: Hydrology. National Engineering Handbook. Soil Conservation Service, Washington, DC.

Van de Giesen, N., Liebe, J. \& Jung, G. 20Io Adapting to climate change in the Volta Basin, West Africa. Current Science 98, 1033-1037.
Van Griensven, A., Francos, A. \& Bauwens, W. 2002 Sensitivity analysis and auto-calibration of an integral dynamic model for river water quality. Water Science and Technology 45, 325-332.

Vigaud, N., Roucou, P., Fontaine, B., Sijikumar, S. \& Tyteca, S. 20II WRF/ARPEGE-CLIMAT simulated climate trends over West Africa. Climate Dynamics 36, 925-944.

Wagner, S., Kunstmann, H. \& Bárdossy, A. 2006 Model based distributed water balance monitoring of the White Volta catchment in West Africa through coupled meteorologicalhydrological simulations. Advances in Geosciences 9, 39-44.

WaterBase 2008a USGS Global Land Cover Characterization (GLCC) Database. http://waterbase.org/download_data.html (accessed 15 July 2016).

WaterBase 2008b FAO/UNESCO Soil Map of the World and Derived Soil Properties. http://waterbase.org/ download_data.html (accessed 15 July 2016).

Zang, C. 2017 Spatial and temporal variability of blue/green water flows in typical meteorological years in an inland river basin in China. Journal of Water and Climate Change 8, 165-176.

First received 6 December 2017; accepted in revised form 14 May 2018. Available online 14 June 2018 